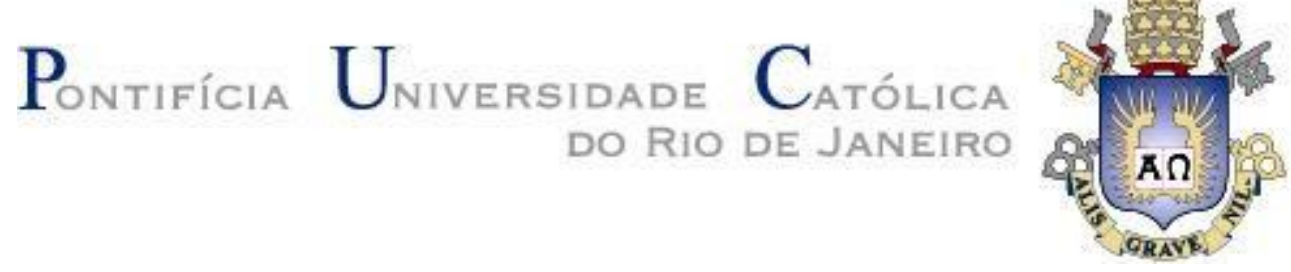

Rebecca dos Santos Alcici

\title{
A mulher como campo de batalha: Um estudo psicanalítico do estupro como arma de guerra
}

\section{Dissertação de Mestrado}

Dissertação apresentada como requisito parcial para obtenção do grau de Mestre pelo Programa de PósGraduação em Psicologia (Psicologia Clínica) do Departamento de Psicologia da PUC-Rio.

Orientadora: Prof ${ }^{a}$ Monah Winograd

Rio de Janeiro

Agosto, 2021 
Rebecca dos Santos Alcici

\section{A mulher como campo de batalha: um estudo psicanalítico sobre o estupro como arma de guerra}

Dissertação apresentada como requisito parcial para obtenção do grau de Mestre pelo Programa de Pós-Graduação em Psicologia (Psicologia Clínica) da PUC-Rio. Aprovada pela Comissão Examinadora abaixo.

Profa. Monah Winograd

Orientadora

Departamento de Psicologia - PUC-Rio

Profa. Maria Isabel de Andrade Fortes

Departamento de Psicologia - PUC-Rio

Profa. Rebeca Nonato Machado

Departamento de Psicologia - PUC-Rio

Rio de Janeiro, 27 de agosto de 2021 
Todos os direitos reservados. É proibida a reprodução total ou parcial do trabalho sem autorização da universidade, da autora e da orientadora.

\section{Rebecca dos Santos Alcici}

Mestranda do Programa de Pós-Graduação em Psicologia Clínica, PUC-Rio.

\section{Ficha Catalográfica}

Alcici, Rebecca dos Santos

A mulher como campo de batalha : um estudo psicanalítico do estupro como arma de guerra / Rebecca dos Santos Alcici ; orientadora: Monah Winograd. - 2021.

85 f. ; $30 \mathrm{~cm}$

Dissertação (mestrado)-Pontifícia Universidade Católica do Rio de Janeiro, Departamento de Psicologia, 2021.

Inclui bibliografia

1. Psicologia - Teses. 2. Estupro como arma de guerra. 3. Trauma. 4. Violência. 5. Guerra. I. Winograd, Monah. II. Pontifícia Universidade Católica do Rio de Janeiro. Departamento de Psicologia. III. Título. 
Dedicatória

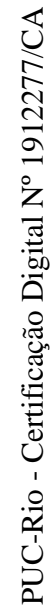

A todas as mulheres que vivenciaram o horror e foram preenchidas pela dor 


\section{Agradecimentos}

À minha orientadora Monah Winograd pela dedicação e apoio na realização deste trabalho.

O presente trabalho foi realizado com apoio da Coordenação de Aperfeiçoamento de Pessoal de Nível Superior - Brasil (CAPES) - Código de Financiamento 001.

Ao Pedro Henrique Rondon pela revisão dedicada e pelo apoio no final desse percurso.

À minha mãe, por todo o acolhimento, amor e inspiração nessa caminhada tão árdua e difícil. Obrigada por me dar os recursos da vida.

Ao meu pai, por todo o carinho, amor e por me incentivar a continuar os estudos.

Ao Gu, pelo companheirismo, amor, afeto e por estar ao meu lado em todos os momentos torcendo pela minha conquista.

À Rapha, pela irmandade e acolhimento nos momentos em que eu mais precisava.

A Ana e Samy, pela amizade de tantos anos e pelo apoio infinito.

À Júlia, por toda a amizade, apoio, carinho e incentivo.

À Gabi, por sempre apoiar minhas conquistas e compreender minhas ausências.

À Natália Cidade, por sempre me acolher nos momentos mais difíceis da minha jornada profissional e acadêmica.

À Ana Paula Lucena, pela escuta analítica que foi/é fundamental para a minha sanidade mental e para o término deste trabalho.

A Raposinha e a Athenas pela companhia em todas as circunstâncias.

A todos que me apoiaram e ajudaram direta ou indiretamente no processo de elaboração deste trabalho, muito obrigada! 


\section{Resumo}

Alcici, Rebecca dos Santos; Winograd, Monah. A mulher como campo de batalha: um estudo psicanalítico do estupro como arma de guerra. Rio de Janeiro, 2021. 85 págs. Dissertação de Mestrado Departamento de Psicologia, Pontifícia Universidade Católica do Rio de Janeiro.

O estupro foi visto durante muito tempo como uma consequência do conflito armado. Contudo, esse cenário mudou na guerra da Bósnia, pois o estupro deixou de ser meramente um efeito colateral da guerra para ser percebido como estratégia/arma de guerra com o principal objetivo de realizar a limpeza étnica. A violência, o estupro e o trauma são os protagonistas da nossa investigação. Nossa pesquisa é de cunho estritamente teórico e, para isso, utilizamos a referência psicanalítica nos baseando principalmente na obra freudiana para pensar a ideia de pulsão de morte, violência, guerra e trauma. Além disso, utilizamos também as considerações de André Green para analisar os conceitos de objetalização e desobjetalização do corpo da mulher nesse processo. Pois percebemos o quanto a mulher é investida como objeto/instrumento de guerra com o fim de um propósito maior - como no caso da guerra da Bósnia, a limpeza étnica - também é totalmente desinvestida e anulada como sujeito, sem poder consentir ao que acontece com seu corpo tornado objeto. Além disso, analisamos o quanto o trauma possui efeitos dessubjetivantes na mulher que passa por essa cena de horror.

\section{Palavras-chave}

Estupro como arma de guerra; Trauma; Violência; Guerra 


\section{Abstract}

Alcici, Rebecca dos Santos; Winograd, Monah (Advisor). A woman as battlegroung: a psychoanalytic study of rape as a weapon of war. Rio de Janeiro, 2021. 85 pages. Masters dissertation-psychology department, Pontifical Catholic University of Rio de Janeiro.

Rape has long been seen as a consequence of armed conflicts. However, in the Bosnian war this setting changed, for rape was no longer merely a side effect of the war, to be seen as a strategy/weapon of war with the main objective of carrying out ethnic cleansing. Violence, rape and trauma are the leading figures of our investigation. Our research is strictly theoretical and for this we use the psychoanalytical reference based on Freud's work to think about the idea of death drive, violence, war and trauma. In addition we also use André Green's considerations to analyze the concepts of objectalization and deobjectalization of the woman's body in such process. As we realize how much women are invested as an object/ instrument of the war with the aim of a greater purpose - as the ethnical cleansing in the Bosnian war - the woman is also totally disinvested and annulled as a subject, without being able to consent to what happens to her body made an object, In addition, we analyze how much trauma has desubjective effects on the woman who goes through such horror scene.

\section{Keywords}

Rape as a weapon of war; Trauma; Violence; War. 


\section{Sumário}

Introdução.

1 - 0 corpo da Mulher como campo de batalha ................................13

1.1 A violência sexual e o estupro............................................ 14

1.2 A dominação da mulher e a violência................................... 15

1.3 Estupro como estratégia de guerra ..................................... 19

1.4 Uma breve ilustração histórica da Ex-lugoslávia e o conflito na Bósnia 22

$1.5 \mathrm{O}$ estupro como estratégia de guerra na guerra da Bósnia e a Limpeza Étnica 26

1.6 Uma breve análise do estupro como estratégia de guerra como genocídio 31

2 - O não consentimento da mulher: violência, guerra e pulsão de

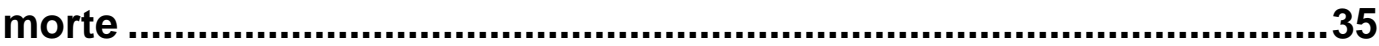

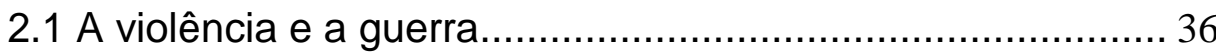

2.2 Percepção freudiana acerca da guerra .................................. 39

2.3 Pulsão de morte: agressão e destruição ................................ 45

2.4 A desobjetalização e a objetalização do corpo da mulher.... 51

3 - Estupro, trauma e guerra 54

3.1 Conceito de trauma na obra freudiana ................................ 54

3.1.1 O primeiro contato com o trauma ……………............. 56

3.1.2 O primeiro tempo do trauma ........................................ 60

3.1.3 Neurose traumática e neuroses de guerra .....................63 63 
3.1.4 O segundo tempo do trauma 67

3.2 Efeitos traumáticos da dessubjetivação pelo estupro na Guerra 71

Considerações finais .74

BIBLIOGRAFIA .78 


\section{Introdução}

A violência, o estupro e o trauma são os protagonistas da nossa investigação. Ginzburg (2012) nos indica que a palavra violência é empregada de diversas formas. O efeito dessa palavra pode se referir a diversos campos de desumanização e hostilidade, como miséria, exploração de crianças e o imperativo da fome. É uma palavra que é utilizada para descrever situações difíceis de extremo horror, de graus de sofrimentos que não deveria haver. Nossa pesquisa se trata de tentar colocar em palavras o indizível e o irrepresentável. Afinal como descrever o horror?

Sabemos de antemão que a mulher teve uma longa trajetória sendo considerada como uma propriedade de seu pai e posteriormente de seu marido. Assim, a construção da relação de poder foi se estruturando de forma desigual, uma vez que a mulher durante muitos anos foi sujeita a esse sistema na qual era submissa ao homem. O estupro, nesse contexto, era visto como crime contra o patrimônio do homem e não contra a mulher.

O estupro durante muito tempo era uma consequência do conflito armado como: na Primeira Guerra Mundial (1914-1918), Segunda Guerra Mundial (19391945), Massacre de Nanquim (1937) e no genocídio de Ruanda (1994). Contudo, esse cenário mudou na guerra da Bósnia (1992-1995), que é nossa proposta de estudo nessa pesquisa, pois o estupro deixou de ser meramente um efeito do conflito para ser percebido como estratégia/arma de guerra. Segundo Diken e Laustsen (2005) o estupro como arma de guerra é distinto de uma agressão sexual cometida por um soldado durante a guerra, pois o estupro utilizado como estratégia de guerra possui um objetivo claro e específico que é principalmente disseminar o trauma destruindo laços familiares e propagando a limpeza étnica em larga escala. A limpeza étnica poderia ocorrer em campos de estupros, nas casas das mulheres ou em bordéis e tinha como principal fim homogeneizar a população. A limpeza étnica foi uma forma de extrema violência na qual eram praticados torturas, assassinatos, estupros sexuais, queima das casas, deslocamento da população.

Esse trabalho surgiu com o objetivo de responder tais questionamentos:

(a) O que seria o estupro como arma de guerra, onde teve maior evidência e com qual objetivo foi realizado?

(b) Qual a perspectiva psicanalítica a respeito da violência e da guerra? 
(c) Como se propagaria o trauma nessas mulheres?

Com a finalidade de responder tais questionamentos nossa investigação se propôs a realizar um estudo estritamente teórico. Para isso, utilizamos nessa pesquisa a referência psicanalítica nos baseando principalmente na obra freudiana para pensar a ideia de pulsão de morte, violência, guerra e trauma. Além disso, empregamos também as considerações de André Green para analisar os conceitos de objetalização e desobjetalização do corpo da mulher nesse processo.

A relevância desse trabalho se dá no âmbito teórico, social e cultural pois se trata de um tema ainda pouco explorado, principalmente no campo da psicanálise. O estupro seja ele em tempos de paz ou guerra atingiu e infelizmente ainda atinge muitas mulheres que precisam de assistência e para isso é necessário que haja profissionais capacitados para cuidar e principalmente escutar a singularidade de cada demanda. Maia (2005) ao observar os relatos do holocausto, nos ajuda a pensar nessa problemática, pois considerando as consequências desse cruel fato, que é o estupro como arma de guerra, para os sobreviventes, os filhos frutos do estupro e os familiares, nos atentamos que é preciso analisar além do aspecto clínico pois há efeitos traumáticos que transcendem deste e precisam ser examinados em uma perspectiva histórica e de transmissão cultural.

A dissertação está organizada como segue. No primeiro capítulo apresentamos o que é a violência contra a mulher, a relação histórica de submissão e desigualdade entre os gêneros e o sistema patriarcal. Além disso, investigamos como se deu o estupro como arma de guerra na Ex-Iugoslávia, principalmente na guerra da Bósnia, o propósito da limpeza étnica e porque podemos considerar como genocídio a prática ocorrida nesse cenário.

No segundo capítulo, analisamos os efeitos da mulher ser usada como mero objeto, sem consentimento do uso do seu corpo, sendo anulada, esvaziada e dessubjetificada enquanto sujeito. Assim, sob a perspectiva freudiana examinamos as repercussões da violência, da pulsão de morte/ pulsão de agressão/ pulsão de destruição que são elementos muito presentes na guerra. Para investigar os aspectos envolvidos na problemática do uso do corpo da mulher como arma de guerra, utilizamos as funções de objetalização e de desobjetalização propostas por André Green, para discutir o uso da mulher nesse cenário de horror.

No terceiro capítulo, a fim de compreendermos os consequências traumáticas que o estupro como arma de guerra poderia causar nas mulheres, nós 
percorremos a trajetória traumática freudiana desde o seu primeiro contato com o trauma em Relatório sobre meus estudos em Paris e Berlim (1886), passando pelo primeiro tempo traumático em Estudos sobre a histeria (1895), percorrendo seus relatos sobre a neurose traumática e de guerra marcada pela selvageria da Primeira Guerra Mundial em 1916 e por fim o segundo tempo traumático manifestado pelo Além do princípio do prazer (1920). Enfim, exploramos os efeitos traumáticos da dessubjetivação causados pelo estupro na guerra. 


\section{O corpo da Mulher como campo de batalha}

As mulheres durante muito tempo foram julgadas como propriedade do seu pai ou de seu marido, sendo assim controladas ou possuídas por este. O estupro, por sua vez, ponderando o cenário da época, era considerado crime contra o patrimônio do homem e não contra a própria mulher. Nos conflitos armados, apesar das leis que a proibiam, muitos acreditavam que a prática do estupro antes da batalha aumentava a agressividade do soldado e constituiria uma oportunidade de liberar as tensões e relaxar.

A presença do estupro nas guerras tem sido acentuada e assustadora desde a Primeira Guerra Mundial, onde os alemães estupraram as mulheres belgas ao invadir a Bélgica, até a guerra da Iugoslávia onde mulçumanas foram estupradas em campos de estupro nos anos de 1990 (Levenkron, 2010). O conflito da Bósnia teve como marco a mudança de pensamento sobre essa temática, uma vez que o estupro começou a ser utilizado e a ser visto como estratégia/arma de guerra e não mais como mera consequência do conflito armado. Destaca-se que o estupro como arma de guerra possui poder naquelas sociedades em que a castidade da mulher é dada com valor moral a ser preservado.

Evidenciamos que o estupro ocorrido na Bósnia tinha como principal objetivo realizar a limpeza étnica, portanto uma ideologia diferente dos casos ocorridos até então. A limpeza étnica, por sua vez, é uma política internacional construída por um grupo étnico ou religioso com o objetivo de retirar de maneira violenta e aterrorizante, de uma área geográfica, uma determinada população civil pertencente a outra etnia ou religião (ONU, 1992). Podemos dizer até que a limpeza étnica pode ser considerada um eufemismo para genocídio, dado que genocídio significa o extermínio parcial ou total de uma comunidade, grupo étnico, racial ou religioso. 


\section{1}

\section{A violência sexual e o estupro}

Com a finalidade de entendermos o estupro como estratégia/arma de guerra, é necessário que possamos primeiramente analisar a definição do que é a violência sexual, como ela é praticada contra as mulheres e o que é o estupro. Segundo Skjelsbaek (2007) a terminologia "violência sexual" é mais associada ao estupro; contudo, esse termo também pode se referir a: "prostituição forçada, escravidão sexual e mutilação genital" (p.70, tradução nossa). O autor ressalta que, segundo Catherine Niarchos (1995), estupro não está relacionado ao sexo, pois é antes de tudo uma expressão agressiva de um sujeito direcionado a outro com exteriorização sexual.

A Organização Mundial de Saúde define violência sexual como um esforço voltado ao fim de uma tentativa ou execução do ato sexual, feito por qualquer pessoa independente do relacionamento com a vítima, sem seu consentimento e podendo ser realizado em qualquer ambiente. A violência sexual compreende o estupro, estabelecido como ato forçado fisicamente, com o objetivo de penetrar a vulva ou o ânus com o pênis, com outra parte do corpo ou até mesmo com o auxílio de objetos (OMS, 2017; Souza 2013). Segundo Bueno (2000), estupro significa: "Ato de abusar sexualmente, com violência, de outra pessoa" (p. 333).

De acordo com a Organização Pan-Americana de Saúde (OPAS) (2018) a violência sexual abarca alguns pontos como:

Estupro dentro de um relacionamento; estupro por pessoas desconhecidas ou até mesmo conhecidas; tentativas sexuais indesejadas ou assédio sexual, que podem acontecer na escola, no local de trabalho e outros ambientes; violação sistemática e outras formas de violência, particularmente comuns em situações de conflito armado (como a fertilização forçada); abuso de pessoas com incapacidades físicas ou mentais; estupro e abuso sexual de crianças; e formas "tradicionais" de violência sexual, como casamento ou coabitação forçada (p. 1).

A Assembleia Geral das Nações Unidas (ONU) proclamou em 1993 uma Declaração sobre a Eliminação da violência contra as mulheres. Esse documento define violência contra as mulheres como: "Qualquer ato de violência de gênero que resulte ou possa resultar em danos ou sofrimento físico, sexual ou psicológico às mulheres, incluindo ameaças de tais atos, coerção ou privação arbitrária da liberdade, seja na vida pública ou na vida privada” (p. 2). Essa declaração afirma 
que as relações de poder entre homens e mulheres foram construídas ao longo da história de maneira desigual e, como consequência, são manifestadas em forma de violência. Assim, as mulheres foram direcionadas a um cenário de dominação e discriminação além de serem impedidas de avançar em suas demandas e pautas. Podemos dizer, então, que a violência contra a mulher é uma ferramenta social fundamental para que as mulheres sejam obrigadas a ocupar posição de subordinação em relação ao homem.

Nesse sentido, a OPAS publicou uma folha informativa sobre a violência contra as mulheres no ano de 2017, afirmando que a violência contra as mulheres, principalmente a violência cometida pelos parceiros - e a violência sexual é considerada uma grande questão de saúde pública e de violação dos direitos humanos e das mulheres. Segundo a Superintendência de direitos das mulheres / Secretaria de Estado de Assistência Social e Direitos Humanos (SUDIM/SEASDH), a violência contra a mulher é vista como um delito contra os direitos humanos e abarca mulheres de todo o mundo.

A ONU reconhece que algumas mulheres pertencentes a grupos minoritários como: indígenas, refugiadas, migrantes, mulheres em comunidades rurais, mulheres carentes, crianças do sexo feminino, mulheres vivendo em instituições, mulheres idosas, mulheres com deficiência e mulheres em conjuntura de conflito armado são especialmente vulneráveis a violência. Nesse sentido, as mulheres vítimas da violência sexual ocorrida como estratégia de guerra são englobadas em um cenário com mais instabilidade e fragilidade.

\section{2}

\section{A dominação da mulher e a violência}

A violência sexual foi entendida durante muito tempo como mera consequência do conflito armado ou como parte de certa economia da guerra. Somente no confronto da Bósnia esse cenário mudou, alertando o mundo para o uso da violência sexual como arma de guerra. A existência dos campos de estupro constituiu fator importante e diferencial nesse conflito. Podemos dizer que surgia naquele momento uma verdadeira arma de guerra com objetivo de destruir nações (Roptin, 2019). Segundo o autor: 
Essa violência sexual joga com elementos sensíveis em certos grupos: a pureza da raça, o status ou a representação da mulher como um símbolo de alta maternidade em princípio intangível ou da mulher como "honra do homem", tornando-se assim aquele por onde vem o infortúnio. (...) O estupro pode afetar a própria existência da comunidade. Portanto, visa difundir ou tornar impura a comunidade (pela transmissão do HIV, por exemplo) (Roptin, 2019, p.1, tradução nossa).

Esse cenário retratado acima foi modificado na convenção de Genebra de 1992, onde a violência sexual passou a simbolizar atos de tortura que atingiam "a integridade ou a saúde física da vítima", diferente do olhar distorcido anterior em que o estupro atacava diretamente a honra do homem e não se preocupava com a saúde física ou mental da mulher (Roptin, 2019). O estupro muitas vezes era realizado como forma de atingir os homens a quem elas "pertenciam". Nos cenários dos conflitos armados, não raro as mulheres, por serem constantemente objetificadas, eram consideradas "prêmios" de guerra a serem atribuídos ao grupo vencedor (Treis \& Morais, 2018).

Brownmiller (1975), afirma que como o estupro não era concebido como uma recusa da mulher, nem muito menos uma opressão imposta pelo homem, o era definido como um crime que incidia na proteção do patrimônio masculino: “O estupro entrou na lei pela porta dos fundos, por assim dizer, como um crime de propriedade de homem contra homem. A mulher, claro, foi vista como propriedade" (p.18, tradução nossa). O estupro se aproximava dos crimes contra a propriedade, como roubo, por exemplo, onde a intenção era de ter e possuir o corpo da mulher. Contudo, a autora, deixa claro que:

A definição feminina do estupro poderia ser expressa em uma simples frase. Se uma mulher escolher não ter relação sexual com um homem específico e este homem decidir prosseguir contra sua vontade, isso é um crime de estupro (p. 18, tradução nossa).

Assim, percebemos que o estupro se trata de um ato praticado na mulher, contra sua vontade e que nem sempre foi visto como crime contra a mulher e sim contra a propriedade do homem. É possível observar que a relação entre homens e mulheres é desigual, e muitas vezes extremamente agressiva, uma vez que somos pautados por uma sociedade patriarcal marcada pela violência contra a mulher e pelo poder voltado para o homem.

Segundo Azevedo (2014), no Império Babilônico o Código de Hamurabi afirmava que a mulher casada que sofresse o estupro seria considerada adúltera e tão culpada quanto seu agressor, não sendo levado em conta o modo como tal ato 
tivesse sido realizado. Desde o Velho Testamento da Bíblia é possível encontrar referências à violação sexual contra a mulher em momentos conflituosos. No quinto dos cinco poemas que compõem o Livro Bíblico das Lamentações, o ato sexual sem a permissão da mulher aparece como uma das punições aplicadas à cidade de Jerusalém no ano de 586 A.C., quando foi devastada (Bíblia, Lamentações, 5:11, p. 819 apud Pereira \& Cavalcanti, 2015). Em trecho de A Ilíada, a ação no primeiro dos dois poemas épicos, é possível observar a utilização das mulheres como recompensa de guerra, ou seja, um "direito" dos guerreiros sobre as mulheres troianas e, ao mesmo tempo, como uma maneira de vingar o rapto de Helena, humilhando os troianos (Moore, 2010; Pereira \& Cavalcanti, 2015).

Hooks (2020), afirma que os homens de todas as raças se interligam com a premissa de que o patriarcado é a única via possível para a sociedade. A autora diz que a postura patriarcal dos homens demonstra não somente a aceitação da norma social baseada na discriminação e na desigualdade contra as mulheres como principalmente um regime político dominado pelo homem. Martins (2016) afirma que:

A estrutura patriarcal no bojo da sociedade capitalista estabelece uma dinâmica de assimetria de poderes e acesso aos recursos econômicos entre homens e mulheres, privilegiando os primeiros. Além disso, essa organização social se mune de instrumentos ideológicos que contribuem com a exploração-dominação das mulheres, os principais são o machismo e a misoginia. Assim, sustentam a hierarquia entre os gêneros ao desvalorizar o que é entendido por feminino ao mesmo tempo em que valorizam o masculino; usam desses princípios para justificar as desigualdades políticas, sociais e econômicas entre mulheres e homens (p.319).

Dessa forma, percebemos o quanto a sociedade pautada no regime patriarcal impôs à mulher intenso silenciamento, dolorosa violência e frequente dominação ao longo do tempo. Destaca-se então que, segundo Saffioti (2015) a desigualdade de gênero:

É posta pela tradição cultural, pelas estruturas de poder, pelos agentes envolvidos na trama de relações sociais. Nas relações entre homens e entre mulheres, a desigualdade de gênero não é dada, mas pode ser construída, é o é com frequência (p.75).

Para Martins (2016), a organização social contemporânea marcada pelo capitalismo está entrelaçada com estruturas como: hierarquias de gênero, classe, etnia/cultura, sexualidade, corporeidades e territorialidades. Assim, a subordinação, exploração e a opressão dos segmentos sociais vistos como inferiores são justificadas e fundamentadas. Tais práticas são, portanto, toleradas e permitidas, 
incentivando as violências praticadas contra essas categorias à margem do sistema - como é o caso das violências praticadas contra as mulheres.

Nesse sentido, visto a tamanha desigualdade de gênero e o sistema patriarcal a que estamos expostos, Seifert (2007), questiona a grande ocorrência do estupro como arma de guerra e a marcante ineficácia dos arranjos internacionais frente a essa questão. A autora indaga que propósito as violações têm nas guerras. O fenômeno do estupro precisa ser explorado em diferentes níveis de discussão, pois envolve distintos aspectos, como, por exemplo: históricos, políticos, culturais, psicológicos e psicanalíticos.

Contudo, de acordo com Seifert (2007), interpretar a violação ocorrida contra a mulher em períodos de guerra como um ato político embasado somente na construção social de gênero é "demasiado míope". Nesse sentido, a autora defende que a desigualdade de gênero não é o único fator presente nessa questão, há ainda a construção cultural da guerra. Destaca-se também que durante esses conflitos, ocorrem diversos ataques sistemáticos ao corpo da mulher e do homem. Corpos são sistemática e densamente feridos, mutilados e mortos.

Por esse ângulo, não podemos afirmar que a acentuada desigualdade de gênero foi o único motivo para a perpetuação do estupro como arma de guerra na Bósnia. Porém, esse componente é extremamente forte e importante nessa grave equação. Hooks (2020) mostra que na sociedade patriarcal homens são incentivados a canalizar agressões frustradas contra as pessoas sem poder - mulheres e crianças (p.172). Além disso, a autora afirma que:

Muito da violência contra mulheres nesta cultura é promovida pelo patriarcado capitalista que incentiva homens a se verem como privilegiados, enquanto diariamente os destitui de humanidade em trabalhos desumanos e, como consequência, eles usam violência contra mulheres para resgatar o senso de poder e masculinidade que perderam (p.173).

Nesse sentido, o patriarcado, para Tiburi (2020), "representa a estrutura que organiza a sociedade, favorecendo uns e obrigando outros a se submeterem ao grande favorecido que ele é, sob pena de violência e morte" (p. 59). A autora mostra que o machismo dentro da lógica patriarcal é o privilégio dos homens e a subestimação de todos os outros; assim, o machismo simboliza "um sistema de crenças em que se aceita a superioridade dos homens devida à sua masculinidade" (p.63). 
Podemos perceber o quanto a violência está presente no modelo patriarcal, machista, político e social em tempos de paz em que estamos inseridos, como também nos conflitos armados em que a mulher tem seu corpo violado, silenciado e usado como estratégia de guerra. Para Saffioti (2015): "trata-se de violência como ruptura de qualquer forma de integridade da vítima: integridade física, integridade psíquica, integridade sexual, integridade moral” (p.18).Percebemos que a violência se faz presente em todas as nuances estudadas até o presente momento: desde a desigualdade de gênero até o uso do estupro como arma de guerra. No próximo tópico iremos aprofundar esse cenário.

\section{3}

\section{Estupro como estratégia de guerra}

O uso do estupro como arma de guerra é uma característica que esteve e está presente em diversos confrontos armados. Nosso trabalho analisa o caso da ExIugoslávia, mais precisamente a guerra da Bósnia, em que a limpeza étnica foi o principal objetivo e o uso da violação sexual como estratégia de guerra foi utilizado à larga: Baylis et al., (2008) estimam que 20.000 a 35.000 mulheres foram violadas durante o conflito da Bósnia.

O estupro como arma de guerra se insere em um contexto em que as problemáticas mencionadas são presentes, porém não são totalitárias. O estupro quando usado como estratégia de guerra ocorre em um cenário mais complexo, onde a desigualdade de gênero está presente, mas não é o principal objetivo. Seria demasiadamente superficial analisar o estupro como estratégia de guerra baseado apenas nessas questões.

O estupro como uma arma de guerra é fundamentalmente diferente do ataque sexual executado por um soldado individual contra uma mulher vulnerável durante um período de guerra. A ONU, no ano de 2014, elaborou um relatório que reconheceu 34 grupos armados. Dentre eles, milícias e forças de segurança do Estado eram responsáveis em 21 países por utilizarem o estupro como estratégia de guerra em locais de conflito.

Segundo esse relatório, a expressão "violência sexual relativa a conflitos" é relacionada a: 
Estupro, escravidão sexual, prostituição forçada, gravidez forçada, esterilização forçada e qualquer outra forma de violência sexual de gravidade comparável perpetrada contra as mulheres, homens ou crianças com uma ligação direta ou indireta (temporal, geográfica ou causal) a um conflito (ONU, 2014. p. 1).

Nesse sentido, pelo fato de ser considerada uma prática tão antiga quanto as guerras, a violação sexual se apresenta como genuína estratégia bélica que é fortemente incentivada e consentida, tornando as mulheres potenciais vítimas (Passos \& Losurdo, 2017). O estupro é considerado uma das estratégias mais devastadoras de um conflito armado, pois tem forte característica de desmoralizar um grupo conquistado. O estupro, ou a ameaça deste, pode fazer com que a população se desloque, saia de seu país a fim de fugir da violência sexual que a invasão pode originar (Vitto, Gill \& Short, 2009).

Além disso, segundo os autores Vitto, Gill \& Short (2009) o estupro como estratégia de guerra também funciona como controle social com o objetivo de sensibilizar a resistência de determinado grupo conquistado. Nesses casos, as violações costumam ocorrer diante dos familiares, onde a vítima, além de estuprada, também é morta e exposta ao público a fim de mostrar à sociedade a importância de obedecer às ordens do invasor. As mulheres, nessas circunstâncias, são escolhidas como alvos devido ao seu gênero, etnia, raça ou até mesmo por serem consideradas pelo grupo inimigo como conspiradoras políticas ou combatentes. Assim, o estupro na guerra opera como portador de ódios profundos como: racismo, preconceito de classe e xenofobia.

Os autores Vitto, Gill e Short (2009) afirmam que, de acordo com Grazyzel (1999), o corpo feminino nesse contexto transforma-se em um campo de batalha simbólico onde as diferenças culturais e geopolíticas são expostas e o ódio é direcionado ao outro promovendo forte desejo de vingança. Nesse sentido, podemos dizer que o estupro é uma das violências mais cruéis e desumanas em relação aos direitos e liberdade das mulheres.

No cenário dos conflitos armados, a violação se torna um símbolo do choque de dois grandes fatores que são pautados em saberes tradicionais da feminilidade e masculinidade: o poder e a impotência. Além do mais, o estupro quando ocorre de forma sistemática, mulheres de um grupo étnico-nacional são acentuadamente afetadas, tornando-se instrumento de genocídio, como foi o caso da região da exIugoslávia (Korac,1998). 
Segundo Skjelsbaek (2007), de acordo com uma análise feminista não é possível considerar o estupro sendo exclusivamente uma ação violenta, pois também é uma manifestação da relação de poder. Esse vínculo de agressor e vítima normalmente é realizado pelo papel do homem e da mulher. Contudo, como os homens também são vítimas desse tipo de violência, é interessante pensarmos na relação de poder como masculinidade e feminilidade: masculinidade, onde está o poder, e feminilidade, onde não há poder, em vez de analisarmos somente papéis de gênero de homem e mulher. Portanto, quando um homem é violentado sexualmente podemos dizer que ele é feminilizado enquanto o agressor do sexo masculino tem sua masculinidade reforçada.

Diante disso, Albanese (2006) afirma que, segundo Brownmiller (1993), além de as vilas terem sido saqueadas ou totalmente destruídas, no conflito da exIugoslávia, as mulheres foram estupradas e essa violação sexual direcionada ao grupo de mulheres inimigas pode ser considerada como uma conquista e satisfação do homem-soldado em violentar um grupo de mulheres que não lhe pertencem.

O estupro que é realizado como estratégia de guerra implica intenção política específica (Moore, 2010). A fim de compreendermos a implicação do termo "estupro como arma de guerra", devemos assimilar que essa violência pode ter diferentes motivações. A diferenciação de diversos tipos de estupro em tempos de guerra se faz necessária para evitar que toda violação realizada durante o conflito seja classificada de acordo com a categoria mencionada (Treis \& Morais, 2018).

Segundo Masengesho Kamuzinzi (2017), o estupro pode ocorrer de três maneiras distintas em meio a guerras. São elas: violações oportunistas, violações motivadas por ódio político e violações genocidas. A primeira se refere às violações cometidas por civis, que tiram proveito da trágica situação que a sociedade está enfrentando, para cometerem abusos sem enfrentar risco de punição. O segundo tipo de estupro também seria realizado por civis a partir da disseminação de uma propaganda de ódio. $\mathrm{O}$ terceiro e último tipo engloba o estupro em massa como arma de guerra, utilizando o abuso sexual como uma das muitas estratégias usadas para destruir determinada comunidade (Kamuzinzi, 2017; Treis \& Morais 2018).

Nessa direção, destaca-se que a violência sexual que estamos nos propondo a investigar, além de ocorrer em tempos de guerra, é realizada com o propósito de estratégia de guerra, ou seja, tal violação visa propagar a destruição de determinada comunidade e/ou nação. Podemos afirmar, então, que a guerra é um grande conflito 
caracterizado pela ameaça à segurança humana, uma vez que oferece pano de fundo para que as violações dos direitos humanos ocorram e até se transformem em parte estratégica da guerra (Crider, 2012).

Para Diken e Laustsen (2005), um dos principais objetivos do estupro como estratégia de guerra é propagar o trauma e consequentemente destruir os laços familiares e a solidariedade de grupo no território inimigo. Além da desmoralização do inimigo, o estupro nesse contexto pode também ser considerado como um componente fundamental da limpeza étnica. Essa violência estratégica contra a mulher durante conflitos abrange uma gama complexa de tópicos que, em sua maioria, são ignorados na literatura, como corpo, gênero, religião e psiquismo. Dessa forma, podemos analisar também que a política e o contexto histórico também são fatores de extrema importância nessa conjuntura, principalmente no contexto que estamos nos propondo a investigar.

\section{4}

\section{Uma breve ilustração histórica da Ex- lugoslávia e o conflito na Bósnia}

Com o objetivo de compreendermos com mais clareza o estupro como estratégia de guerra, é necessário compreendermos o cenário em que ocorreu a guerra da Bósnia, que se efetuou nos anos de 1992 a 1995. Segundo Bassanetti (2014) a Iugoslávia até o início dos anos noventa era composta por seis repúblicas: Sérvia, Macedônia, Croácia, Eslovênia, Montenegro e Bósnia-Herzegovina. Faziam parte do país duas províncias autônomas, Kosovo e Vojvodina. Segundo a autora, o desequilíbrio econômico entre as repúblicas foi ficando cada vez mais evidente e as repúblicas mais ricas (Sérvia, Eslovênia e Croácia) foram se destacando cada vez mais. Por conseguinte, no final da década de 80, a Eslovênia foi responsável foi $80 \%$ de todo o PIB da Iugoslávia, mas possuía apenas $8 \%$ da população.

De acordo com Albanese (2001), a fim de entendermos o abuso sexual contra a mulher na guerra é necessário percebermos em que contexto a violência foi desencadeada. No caso específico da ex-Iugoslávia, a autora destaca que o contexto era de grande crescimento do nacionalismo e quebra das federações, que gerou diversas crises na região, além de cruéis confrontos étnicos. 
As inúmeras fragmentações de impérios, filosofias e teologias que atingiram os Bálcãs atuaram na criação do Estado iugoslavo com diferentes povos e culturas. Essas divergências em alguns momentos eram atenuadas e, em outros, acentuadas; contudo, sofreram seu ápice na guerra civil da década de 1990 (Aguilar \& Mathias, 2012).

Aguilar e Mathias (2012) descrevem a situação geopolítica da antiga Iugoslávia no início dos anos 1990 como:

Um país com dois alfabetos (cirílico e latino), três línguas (esloveno, macedônio e servo-croata), quatro religiões (católica, ortodoxa, muçulmana e judaica), cinco nacionalidades (eslovena, croata, sérvia, muçulmana e macedônia) além de várias minorias nacionais como húngaros, búlgaros, albaneses, etc., e seis repúblicas (Eslovênia, Croácia, Sérvia, Bósnia-Herzegovina, Macedônia e Montenegro). Foi nessa colcha de retalhos que se deu a guerra civil do final do século XX (p. 443).

Nesse cenário, destaca-se que, no final da Segunda Guerra Mundial, devido a questões políticas internas, o então chamado Reino da Iugoslávia passou a ser nomeado de República Federativa Socialista da Iugoslávia. Embora houvesse seis repúblicas nessa federação e nenhuma identificação de nacionalidade entre os povos, eles se mantiveram relacionados por mais de quarenta anos (Belançon \& Munhoz, 2015).

O ano de1980 foi marcado pela morte do Marechal croata Josip Broz Tito, que exerceu a presidência da ex-Iugoslávia de 1953 a 1980. Tito teve sua trajetória como militante comunista e líder dos Partians, grupo guerrilheiro de resistência à invasão das potências do Eixo, durante a Segunda Guerra (Aguilar, 2003). Além disso, também tinha exercido o cargo de Primeiro-Ministro da ex-Iugoslávia durante os anos de 1945 a 1953, no exercício de governo do presidente Ivan Ribar. No ano de 1953 tomou posse do cargo de presidente e governou até sua morte em 1980 (Belançon; Munhoz, 2015).

Tito teve importante papel histórico e político no processo de formação e singularidade do povo iugoslavo como uma República Socialista. Assim, obteve a Iugoslávia consistente com o objetivo de que nenhuma das seis repúblicas se sobressaísse às demais e colocasse em risco o equilíbrio do país (Belançon \& Munhoz, 2015). Nesse sentido, Tito amparou com mais cuidado a BósniaHerzegovina devido a sua multietnicidade e consequentemente sua fragilidade. De acordo com Alves (2003) foi enquanto Tito estava no poder que ser mulçumano na Bósnia-Herzegovina foi caracterizado como "nacionalidade". 
Após seu falecimento, foi substituído por uma direção colegiada das repúblicas federadas. Posteriormente a esse acontecimento, os problemas socioeconômicos da antiga Iugoslávia afloraram. As repúblicas mais pobres criticavam o descaso político que ocorria no gerenciamento do orçamento federal liderado pelos Sérvios. A Eslovênia e a Croácia eram as repúblicas mais desenvolvidas economicamente, recebiam investimentos federais no turismo e na indústria; consequentemente, exigiam mais poder político dentro do Estado. As diferenças econômicas acentuaram ainda mais a discriminação e as questões étnicas (Aguilar \& Mathias, 2012; Vizentizi, 1999). No ano de 1991 as repúblicas da Croácia e Eslovênia, proclamaram sua independência. A Sérvia, por sua vez, desejava criar a Grande Sérvia, contando para isso com o território da BósniaHerzegovina. Apesar do cenário de apreensão, houve um processo de votação para a independência da Bósnia-Herzegovina, onde 99,45\% dos votos foram a favor da separação. Contudo, esses votos representavam apenas $63,4 \%$ da população, pois $5 \%$ da população que eram compostos de Sérvios que eram contra a independência, se abstiveram devotar (Bassanetti, 2014). Após a votação, o conflito aumentou na região:

Os sérvios cercaram Sarajevo, a capital da Bósnia, e ocuparam boa parte do país, dizimando principalmente os muçulmanos, além dos croatas, com o objetivo de fazer emergir uma República Sérvia. Dentre as atrocidades cometidas, estão a limpeza étnica e os estupros em massa (Bassanetti, 2014, p.50).

É necessário destacarmos que a Bósnia por sua vez, possuía maior miscigenação de etnias entre as repúblicas da ex-Iugoslávia. Segundo Bassanetti (2014) a Bósnia era formada basicamente por três grupos:

Os bósnios de origem sérvia, que representavam cerca de um terço do país e eram cristãos ortodoxos; os bósnios de origem croata, que eram a minoria, e os bósnios muçulmanos, que constituíam quase a metade do país. Os bósnios croatas e muçulmanos defendiam a independência da Bósnia, mas os bósnios sérvios eram contra por defenderem a criação de uma "Grande Sérvia", que incluiria porções da Bósnia e Herzegovina e da Croácia, além da própria Sérvia (p. 49).

Os autores Snyder, Gabbard, May e Zulcic (2006) afirmam que, segundo Gellner (1983), a crise econômica foi extremamente marcante e desmoralizante para a maioria dos iugoslavos. Como consequência da instabilidade econômica, o 
sentimento de perda de identidade social e o desnorteamento em relação ao futuro eram extremamente presentes e marcantes na população.

Nesse cenário regado pelas inconstâncias, a ideologia do nacionalismo étnico se tornou uma saída para muitos iugoslavos. O conceito de nacionalismo é baseado na ideia de que as pessoas estão divididas em nações e que cada uma delas tem autorização para ser uma unidade autônoma.

A palavra nationality (nacionalidade) é derivada do latim, onde natio significa: para o nascido. Esse prefixo sugere uma descendência racial ou biológica comum. Isto é, para o nacionalismo, seu grupo étnico é baseado na biologia e na transmissão, uma vez que a memória cultural e histórica de cada uma das gerações pode ser lembrada ou imaginada (Albanese, 2006 apud Ignatieff, 1993; Calhoun, 1993; Hayes, 1960). Conforme Peres (2013) no caso da Bósnia:

A definição nacional de "sérvios", "croatas" e "muçulmanos" é posterior à existência dos grupos em si. Tal definição tem raiz religiosa, mesmo quando a pessoa é ateia, ou não é religiosa; os sérvios representariam os cristãos ortodoxos; os croatas, os católicos; e os muçulmanos, aqueles adeptos do islamismo. A partir de 1993, o termo oficial para designar os muçulmanos passou a ser "bosniac" (p. 122).

Conforme Aguilar e Mathias (2012) os movimentos separatistas foram crescendo cada vez mais e os investimentos dos recursos foram conduzidos para o campo militar, impossibilitando os empenhos nos demais campos, enfatizando as desigualdades econômicas e causando cada vez mais insatisfação e hostilidade entre os grupos étnicos. Assim, de acordo com os autores:

Os diversos problemas econômicos e políticos no interior do Estado, a falta de uma liderança, a luta por manter a estrutura de poder e a gerência dos recursos resultaram no paulatino fortalecimento da identidade dos diferentes grupos e na sua coesão interna. Da mesma forma, acentuou-se e até inventou-se diferenças em relação aos demais. A massiva propaganda estatal ajudou a criar imagens dos outros como inimigos, como perigo para a segurança pessoal e coletiva de cada grupo. As questões econômicas misturam-se às étnicas e a manipulação e construção das identidades foram fortes e apelativas emocionalmente. Quando o Estado iugoslavo ruiu, os diversos grupos praticaram crimes contra a humanidade, conhecidos como limpeza étnica (p. 452).

Dessa forma, os Estados que foram sendo construídos em consequência da guerra civil são compostos de forte elemento nacionalista, a fim de evidenciar sua cultura e identidade. $\mathrm{O}$ estupro como estratégia de guerra com o objetivo de realizar a limpeza étnica foi muito utilizado nesse conflito, pois tinha como propósito 
homogeneizar a população e evidenciar somente uma nacionalidade. Para atingir tal objetivo, cada Estado foi desenvolvendo símbolos únicos a fim de se diferenciar das outras nações vizinhas. A violência foi tão marcante e severa que impossibilitou, na contemporaneidade, o estabelecimento de instrumentos coletivos, como era realizado anteriormente, na região que já foi nomeada de Iugoslávia (Aguilar \& Mathias, 2012).

\section{5}

\section{O estupro como estratégia de guerra na guerra da Bósnia e a Limpeza Étnica}

O estupro não pode ser entendido "somente" como efeito colateral infeliz da guerra. $\mathrm{O}$ estupro é literalmente uma arma de guerra. $\mathrm{O}$ demasiado uso do estupro como estratégia de guerra foi utilizado mais recentemente na ex-Iugoslávia (principalmente na guerra da Bósnia, no período de 1992 a 1995, na guerra do Kosovo, nos anos de 1998 a 1999) e na guerra civil em Ruanda, que ocorreu durante os anos de 1990 e 1994, Libéria, que se procedeu durante o período de 1999 a 2003, e Uganda, que transcorreu no decorrer dos anos de 1981 a 1986 (Diken \& Laustsen, 2005).

Pode-se afirmar que, na última década do século XX, houve aperfeiçoamento significativo do uso do estupro na guerra. Durante a guerra da ex-Iugoslávia, no início dos anos 90, o exército sérvio exerceu, principalmente sobre a Bósnia, o uso excessivo do estupro como ferramenta de limpeza étnica (Moore, 2010).

Com a finalidade de entendermos o porquê do principal objetivo de o estupro como estratégia de guerra na Ex-Iugoslávia e na guerra na Bósnia ser a limpeza étnica. precisamos brevemente entender que tais conflitos tinham como problemática central uma série de desentendimentos religiosos, identitários, étnicos, nacionais e territoriais que possibilitaram guerras regadas de violência e barbaridade. Esses confrontos estruturaram a região de acordo com a etnia e reorganizaram as categorias étnico-nacionais em sérvia, croata e muçulmana. Nessa perspectiva, Peres (2011) afirma que:

A guerra na Bósnia-Herzegovina é um marcador fundamental dos processos identitários que se desenrolaram naquele território, dado que foi uma guerra cujas categorias nacionais - "muçulmanos", "sérvios" e "croatas" - definiram os lados do conflito e tendo em vista que foi uma guerra caracterizada pela violência hedionda e pela limpeza étnica, via expulsão, agressão, assassinatos, tortura, 
estupros, massacres e medo, que levou à reorganização populacional e à divisão do território (p. 124).

A fim de compreendermos com mais precisão o processo da limpeza étnica, é preciso ressaltar que a Sérvia iniciou o processo de limpeza étnica no território da ex-Iugoslávia visando a construção de uma Grande Sérvia (Fernandes, 2006 apud Oliveira \& Junior, 2019). Com a finalidade de atingir esse objetivo de homogeneizar a população, o estupro foi utilizado com uma finalidade de procriação, tortura e destruição.

Segundo Salzman (1998), o estupro muitas vezes foi considerado um subproduto inevitável das guerras passadas. Entretanto, esse cenário se modificou na guerra da Bósnia, pois como o conflito tinha como principal objetivo a limpeza étnica, o estupro foi excessivamente utilizado como prática genocida, trazendo novas repercussões para a comunidade internacional. Assim, pode-se afirmar que a guerra é marcada por inúmeras manifestações e ferramentas de violência que possuem como meta atingir certos propósitos políticos e estratégicos. Contudo, a violação sexual não tinha sido até então considerada uma violência com a mesma gravidade que a tortura e os assassinatos. Com isso, essa perspectiva anulava a possibilidade de o estupro ter algum objetivo estratégico na guerra (Skjelsbaek, 2007).

Diante desse cenário, observamos que os acontecimentos da guerra da Bósnia se revelaram muito mais complexos do que a maioria dos estudos sobre a temática do estupro como arma de guerra, onde sintetizam a mulher como vítima e o homem-soldado como agressor. As vítimas não se reduziram apenas às mulheres; em alguns casos, os familiares eram forçados a estuprar uns aos outros ou até mesmo obrigados a presenciar um membro da família sendo estuprado. Em relação ao agressor, os homens, muitas vezes, eram obrigados a estuprar como parte de um ritual de iniciação e, caso se negassem a realizar tal violência, eram humilhados, ou até mesmo castrados e mortos. O estupro utilizado nessa situação tinha objetivos claros: distinguir as nacionalidades de sérvios, muçulmanos e croatas que até então estavam muito homogêneas (Diken \& Laustsen, 2005).

A sociedade patriarcal do Estado Sérvio, dos militares e da Igreja Ortodoxa contribuíram para construir uma concepção na qual a mulher, sérvia ou não, seria apenas uma reprodutora com o objetivo de cumprir o nacionalismo sérvio e produzir cidadãos visando povoar a nação. Para Salzman (1998), essa crença sobre 
a mulher provavelmente influenciou a forma como seu corpo foi violentado, usado e inserido em campos de estupro para alcançar a limpeza étnica. Os estupros podiam ocorrer nas casas das mulheres, bordéis, ou até mesmo em campos de estupro (Salzman, 1998; Diken \& Laustsen, 2005). Segundo Salzman (1998), o Estado Sérvio parece ter usado metodicamente o estupro como estratégia de guerra com o principal objetivo de realizar uma limpeza étnica, podendo ser considerado até um eufemismo para genocídio. A resolução 780 realizada pelo grupo de especialistas da ONU em 1992, afirmou que a limpeza étnica foi:

Realizada por meio de assassinato, tortura, prisão e detenção arbitrárias, execuções extrajudiciais, estupros sexuais, confinamento da população civil em gueto, remoção forçada, deslocamento e deportação da população civil, ataques militares ou ameaça de ataques civis em áreas civis e destruição de propriedades. Essas práticas constituem crimes contra a humanidade e podem ser assimiladas a específicos crimes de guerra. Além disso, esses atos podem também se enquadrar no significado de convenção de genocídio (p. 33, tradução nossa).

Mullins (2009) mostra que os genocídios produzem grandes índices de violência sexual. Dessa forma, podemos dizer que o estupro como arma de guerra é uma forma de genocídio e, por sua vez, um crime contra a humanidade. Nesse sentido, conforme Peres (2011), a limpeza étnica foi:

Fundamental para a homogeneização populacional do território, realizou-se através da transferência de população (literalmente, um ônibus pegava as pessoas em casa e as levava até o território sob domínio dos seus), expulsão e extermínio. Queimas de casas, templos religiosos e plantações, estupros, torturas e assassinatos contribuíram nesse processo, que, podemos dizer, foi bem-sucedido - ao dividir o território, separando pessoas com base em sua ascendência étnico-nacional-religiosa e fazendo com que o antigo modo de vida, baseado na coexistência e na heterogeneidade, passasse a ser inconcebível (p.125).

Mullins (2009), aprofunda a questão dos estupros afirmando que, na ExIugoslávia, foram criados centros de detenção onde mulheres foram estupradas compulsoriamente até que ficassem grávidas, sendo mantidas em cativeiro até que atingissem gestação avançada, onde não pudessem mais abortar (Mullins, 2009; Diken \& Laustsen 2005; Salzman 1998). Carregar um filho resultante de um estupro pode ser considerado como uma tortura extremamente cruel ou também como parte estratégica da limpeza étnica (Diken \& Laustsen, 2005). Nessa perspectiva, Peres (2013), afirma que:

Nos campos de estupro, geralmente escolas, armazéns, ginásios, hotéis, as mulheres - principalmente as bosniaquinhas (muçulmanas bósnias) - eram obrigadas a ter relações sexuais com mais de um soldado e várias vezes. Algumas ficavam presas durante meses até engravidarem e não poderem mais abortar. Em termos numéricos, 
calcula-se que cerca de vinte mil mulheres muçulmanas e croatas foram estupradas durante a guerra (p. 119).

Segundo a ONU (2014), cerca de vinte mil mulheres sobreviveram às numerosas violações e torturas na Bósnia durante o período de 1992 a 1995. Evidencia-se que há silêncio sobre o estupro em massa e questionamentos indispensáveis que não foram respondidos. Essas perguntas estão relacionadas às crianças que foram fruto e resultado de dessa cruel violência intercomunitária (Todorova, 2011).

Além disso, algumas questões referentes à gravidez como consequência do estupro e à situação dessas crianças nascidas como resultado prático dessa violência brutal, necessitam de mais pesquisa e informação com o propósito de obter respostas. A mulher engravida como fruto de uma violência sexual e é confrontada com serviços ilegais e procedimentos inseguros para realizar o aborto, colocando em risco sua vida. Além disso, há grande chance de a vítima contrair doenças sexualmente transmissíveis, dentre elas o HIV. Em contrapartida, não existe, nesses locais, acesso absoluto à profilaxia dessa doença (ONU, 2014).

Ressaltamos que, para algumas autoras como Copleon (1994), a gravidez forçada, marcante na prática do estupro em tempos de guerra da ex-Iugoslávia, evidencia também forte componente de gênero. A gravidez involuntária na sociedade patriarcal é considerada natural, divinamente ordenada ou uma ação inquestionável. Consequentemente, o risco de uma gestação por meio do estupro não é considerado uma injúria, mas um efeito.

O cenário mudou no conflito na Bósnia, quando a gravidez forçada tinha como principal objetivo prejudicar a raça inimiga. Conforme um olhar feminista, o fato de as mulheres muçulmanas serem forçadas a terem filhos sérvios, não é simplesmente um dano étnico. Nesse paradigma, a gestação forçada se assemelha a um ataque à autonomia reprodutiva das mulheres, assinalando o forte desejo de marcar o estupro e o estuprador no corpo e na vida da mulher. A objetificação das mulheres também é ponto marcante, pois um dos principais objetivos do estupro consiste em humilhar os homens ou destruir "o inimigo", uma vez que uma mulher é atacada por ser considerada pertencente a um homem, e nesse instante sua subjetividade é totalmente negada (Copleon, 1994).

De acordo com o relatório da ONU (1992), a forma sistemática como o estupro foi cometido, com o objetivo de realizar a limpeza étnica, revela fortemente 
a possibilidade de ser produto da política. Nesse sentido, a política por trás desses eventos se mostra mais evidente, uma vez que houve grande fracasso quanto a impedir tais crimes, processar e punir os agressores. Segundo esse mesmo relatório havia cinco principais padrões de violação que ocorriam no conflito da ExIugoslávia. Nesses padrões nota-se uma logística forte, principalmente dentro dos campos de estupro. Dentre os cinco padrões destacamos o terceiro e quarto, relevantes para o nosso estudo. No terceiro padrão, os estupros ocorreram em centros de detenção, após a invasão das cidades ou vilas durante os conflitos armados. Enquanto os homens, aqueles que tinham idade de lutar, eram torturados, mortos ou direcionados a campos de trabalho, as mulheres eram levadas para campos diferentes. Nesses locais, soldados, paramilitares e até mesmo civis violentavam sexualmente as mulheres. $\mathrm{O}$ quarto padrão diz respeito à violência contra as mulheres realizada em campos de estupro, como edifícios, bordéis, restaurantes, hospitais e fábricas.

Alguns autores afirmam que a guerra atingiu seu objetivo último, uma vez que os estupros em massa ocorridos na Ex-Iugoslávia, geraram crianças com etnias mistas, trazendo duas consequências tanto para a nação quanto para as mulheres. A primeira delas foi o lembrete constante da humilhação e derrogação da nação como um todo e as crianças que sobreviveram foram consideradas símbolos da experiência de genocídio. A segunda foi o fardo social que essas mães e filhos carregaram e ainda carregam, sendo frequentemente afastadas de suas famílias (Mullins, 2009; Diken \& Laustsen 2005; Salzman, 1998). Ressalta-se também que em determinados grupos onde a linhagem é determinada por meio de paternidade patrilinear, os filhos frutos dessa violência pertencem à etnia do pai e não à da mãe, podendo modificar a subjetividade daquela determinada comunidade em relação à etnia e à identidade (Mullins, 2009; Salzman, 1998).

Contudo, diferente do que alguns pesquisadores acentuam, Peres (2013) afirma que a guerra não atingiu seu propósito definitivo, pois a Bósnia continuou na condição de Estado, as mulheres que sofreram a violação não foram rejeitadas por suas famílias e, por fim, os bebês frutos dessa violência não se "tornaram sérvios". Contudo, apesar disso, o estupro se mostrou uma estratégia que, mais do que qualquer outra, trouxe à tona a particularidade do sofrimento, impedindo mesmo após a guerra, qualquer aproximação dos refugiados com suas casas e vilas. 
Isso posto, notamos divergências entre os autores em relação ao cenário pósguerra e analisamos que mesmo se o objetivo principal desse conflito não tiver sido totalmente atingido como esperado, o seu processo ocorreu de forma extremamente cruel e agressiva. A violência sexual contra as mulheres no conflito da ExIugoslávia foi realizada de modo maciço com a finalidade de realizar limpeza étnica. Vimos que, nesse caso, não é possível simplificar a questão somente na mulher como vítima e o homem-soldado como o agressor, pois homens e crianças também foram estuprados ou sofreram violência sexual (Peres, 2011).

\section{6}

\section{Uma breve análise do estupro como estratégia de guerra como genocídio}

Em 1944, Raphael Lemkin, cidadão polonês e judeu, a fim de conseguir nomear as atrocidades dos nazistas contra os judeus, criou o termo genocídio. Conforme o autor, genocídio é uma palavra nova para designar práticas antigas no novo mundo, que significa a destruição de uma nação ou de um grupo étnico. A palavra Genocídio foi pensada a partir de genos, de origem do grego antigo que tem sentido de raça, tribo com o sufixo latino (cide) que quer dizer matança. Existente em palavras como tiranicídio, homicídio e infanticídio.

Segundo os autores Vito, Gill e Short (2009), a influência, luta e empenho de Raphael Lemkin auxiliou consideravelmente para que no ano de 1948 fosse elaborada uma Convenção da ONU para a Prevenção e Punição do crime de Genocídio. Esse documento determina que o genocídio ocorrido em tempos de paz ou guerra seja considerado crime do direito da população, que deve ser prevenido e punido. $\mathrm{O}$ artigo segundo dessa declaração define genocídio como:

Qualquer dos seguintes atos, cometidos com a intenção de destruir, no todo ou em parte, um grupo nacional, étnico, racial ou religioso, tal como:

(a) assassinato de membros do grupo;

(b) dano grave à integridade física ou mental de membros do grupo;

(c) submissão intencional do grupo a condições de existência que lhe ocasionem a destruição física total ou parcial;

(d) medidas destinadas a impedir os nascimentos no seio do grupo;

(e) transferência à força de menores do grupo para outro grupo. (p.2) 
Lemkin (1944) apresenta que pode ser considerado um ato genocida quando há assassinato em massa de todos os membros de uma nação ou quando não há obrigatoriamente uma destruição direta instantânea de um povo. Ou seja, o genocídio consiste também na elaboração de um plano que visa à destruição de fundamentos básicos para a vida dos grupos nacionais com a principal finalidade de destruir esses grupos. Assim, esses planos consistiriam em desintegrar as políticas sociais e culturais como idioma, sentimentos nacionais, religião, liberdade, segurança pessoal, dignidade e até mesmo a vida dos sujeitos integrantes desse grupo. Podemos dizer então que o genocídio pode ser analisado como: "uma negação do direito à vida de certos grupos humanos" (Vito, Gill \& Short, 2009, p. 36).

Mullins (2009) destaca ainda que o estupro genocida é organizado pela tática militar, utilizado como estratégia de guerra para propagar medo em populações moderadas, humilhar homens e mulheres, derrogar as mulheres (através da destruição de sua identidade) e gerar um grupo de crianças étnicas mistas com o intuito de humilhar, deteriorar e dominar. A humilhação da comunidade do sexo masculino também é um dos grandes objetivos do estupro em tempos de guerra, pois os homens muitas vezes eram obrigados a assistir quando suas esposas e filhas estivessem sendo violentadas.

Biehler (2002) afirma que, de acordo com Askin (1997), o estupro era extremamente usual nos conflitos e foi utilizado durante séculos, portanto não houve por muito tempo a atenção devida. Esse cenário se modificou quando veio à tona a verdadeira face das violações em massa que ocorriam na Bósnia no início dos anos 90. Essa notícia causou verdadeiro choque na sociedade, pois o estupro sistemático com o objetivo de realizar limpeza étnica abarcava demasiada brutalidade e violava os direitos humanos internacionais em geral. Entrou em cena pela primeira vez o conceito "estupro como crime de guerra". Assim, formulou-se o Tribunal Penal Internacional para a ex-Iugoslávia (Vitto, Gill \& Short, 2009).

É necessário ressaltar que a guerra é considerada uma grande ameaça à segurança humana, pois é evento que gera inúmeras violações aos direitos humanos. A principal e mais importante resposta internacional às consequências de segurança humana gerada pela guerra foi a elaboração do Tribunal Penal Internacional (TPI), supervisionado pelo Conselho de Segurança das Nações Unidas (Crider, 2012). Segundo o Comitê Internacional da Cruz Vermelha (2010): 
Os tribunais internacionais existem desde o início do sistema internacional moderno. Sua finalidade é dissolver as diferenças entre Estados ou, às vezes, entre outras entidades internacionais. No entanto, foi somente nos julgamentos de Nuremberg, após a Segunda Guerra Mundial, que foram criados os tribunais ad hoc destinados a resolver causas penais iniciadas contra particulares para encarar os crimes internacionais mais graves, como o genocídio, os crimes de guerra e os crimes contra a humanidade (p. 1).

O tribunal penal da ex-Iugoslávia marcou uma etapa final de reconhecimento da necessidade de uma instituição legal capaz de averiguar os direitos humanos e os descumprimentos de segurança em tempos de paz e guerra. A transformação na percepção da importância dos direitos humanos e do sujeito originou um contexto em que foi possível elaborar uma lei internacional que garantisse os direitos das mulheres violentadas na guerra (Crider, 2012). Segundo Turra e Obregón (2019), o Tribunal Penal Internacional para a ex-Iugoslávia foi o primeiro a ser considerado efetivamente inserido pelas Nações Unidas com a finalidade de determinar a criminalidade penal individual dentro do direito humanitário.

Em relação ao genocídio, os autores Vitto, Gill e Short (2009) afirmam que:

O foco crítico do genocídio, entendido como um crime internacional, é a proteção de grupos humanos inteiros. Chamado com frequência de o mais grave dos crimes internacionais, o genocídio é influenciado pelo "direito de viver" dos indivíduos. Porém, a preocupação é com o "direito à existência" de grupos humanos e não de indivíduos. Essa formulação do genocídio parece contrastar com o conceito corrente de direitos humanos com sua ênfase no indivíduo. A Convenção de 1948 lista os seguintes grupos que poderiam ser alvo de genocídio: nacionais, étnicos, raciais e religiosos (p. 36).

Nesse sentido, podemos afirmar que o genocídio é, sem dúvida, uma transgressão contra um grupo como um todo. Contudo, as ações genocidas são realizadas contra os sujeitos integrantes desses grupos. Os membros pertencentes a essas comunidades são mortos, estuprados e feridos. O estupro qualificado como genocídio é considerado uma violação contra a autonomia do sujeito, como também uma violação contra todo um grupo. Assim, quando devidamente classificado como genocídio, o estupro pode ser entendido como ferramenta eficiente dessa prática, pois é uma forma de atacar gravemente o corpo ou a saúde mental de um grupo (Vitto, Gill \&Short, 2009).

Alguns autores enfatizam a importância de reconhecer as diferenças existentes entre o estupro ocorrido em tempos de paz e de guerra, portanto não 
podemos perder de vista os pontos em comum. Segundo Copleon (1994): "todo estupro é violação grave da integridade física e mental. Todo o estupro tem o profundo potencial de debilitar, para tornar a mulher sem-teto em seu próprio corpo e destruir sua sensação de segurança no mundo" (p. 265, tradução nossa).

Dessa forma, apesar da afinidade entre o estupro realizado em tempos de paz e guerra, ressaltamos que existem diferenças entre os cenários em que ocorrem as violações, principalmente quando mencionamos o caso da ex-Iugoslávia que fez repensar o significado sobre o estupro nos conflitos armados.

Percebemos o quanto é presente a violência propagada de um grupo a outro, que possui como principal objetivo destruir cada um dos indivíduos daquele povo. No caso na Bósnia, notamos que, para atingir esse fim, a limpeza étnica era necessária e para isso o estupro foi utilizado como estratégia. Nesse caso, o estupro, a limpeza étnica e o genocídio foram fatores que estavam pela primeira vez nitidamente juntos e presentes em um conflito.

Esses atos violentos e cruéis, que relatamos neste capítulo, foram praticados por soldados a serviço do Estado; e com o propósito de compreender com mais clareza como opera esse processo das decorrências de um grupo e da agressividade direcionada ao outro, vamos, no próximo capítulo nos dedicar a analisar os efeitos da violência, da guerra, da destrutividade e da pulsão de morte. 


\section{2}

\section{O não consentimento da mulher: violência, guerra e pulsão de morte}

A violência é considerada fator presente, comum e corriqueiro na sociedade, pois é uma das principais características inerentes ao ser humano. A guerra, por sua vez, exige da violência sistematização e organização. Freud explorou o tema da violência e da guerra principalmente nos textos: Considerações atuais sobre a guerra e morte (1915) e Por que a guerra? (1932). É importante ressaltar o texto divisor de águas, escrito por Freud em 1920, "Além do princípio do prazer", contendo inúmeras considerações pertinentes, como por exemplo a segunda teoria pulsional que acompanhará o enredo da obra até a morte de Freud.

A segunda teoria pulsional abarca a dualidade entre pulsão de vida e pulsão de morte, responsável pela vida humana. Além disso, essa teoria é fundamental para compreendermos fatores como a pulsão de agressão e a pulsão de destruição que são elementos presentes nas ações de violência humana.

Nosso trabalho tem, como um dos principais pilares, estudar o corpo da mulher como campo de batalha, e de que maneira sua individualidade é anulada e sua subjetividade é negada em contextos de violência e guerra. Para isso precisamos entender conceitos fundamentais da teoria psicanalítica, como o de pulsão de morte/ pulsão de agressão/ pulsão de destruição/ articulados às funções de objetalização e de desobjetalização. Quando falamos do corpo da mulher como arma de guerra, principalmente no caso ilustrado pela guerra da Bósnia, estamos nos referindo a dois principais processos de objetificação: 1. O corpo da mulher é usado sem seu consentimento como estratégia de guerra; 2. sua existência fica subordinada ao homem no contexto da guerra. Dessa forma, não somente seu corpo é violado como também sua singularidade e sua voz - ou seja, sua subjetividade - são anuladas. Podemos pensar nestes casos a relação de objeto como eminentemente dominada por processos de destruição de certos outros. O estupro como arma de guerra é um cenário paradigmático que nos permite analisar o trauma a partir do viés da anulação da singularidade desejante da mulher e do não consentimento dela.

Diante desse cenário, ressaltamos que da mesma forma que há desobjetalização da subjetividade da mulher, - ou seja, sua dessubjetivação - seu 
corpo é altamente objetalizado com o propósito da construção de uma arma de guerra, produzindo o mesmo efeito desobjetificante e objetificante.

Nesse contexto complexo, podemos dizer, portanto, que temos um paradoxo: uma vez que a mulher ao mesmo tempo é investida como objeto/instrumento de guerra com o fim de um propósito maior - como no caso da guerra da Bósnia, a limpeza étnica - também é totalmente desinvestida e anulada como sujeito alteritário, sem poder consentir ou não ao que acontece com seu corpo tornado objeto.

\section{1}

\section{A violência e a guerra}

A violência se fez presente em todas as circunstâncias analisadas até o presente momento neste trabalho. Violência, segundo o dicionário Michaelis, significa: "qualidade ou característica de violento; ato de crueldade; emprego de meios violentos; fúria repentina; coação que leva uma pessoa à sujeição de alguém" (p. 1). Já o adjetivo "violento" de acordo com o mesmo dicionário, significa:

que atua com forma ou impetuosidade, teso; caracterizado pelo emprego da violência ou da força bruta; que revela grande ira; demasiadamente agitado; que se manifesta descontroladamente; que demanda muita força, que exaure as forças; diz-se da morte causada pela força ou por acidente; contrário à razão, ao direito, à justiça (p.1).

Arendt (2016) afirma que a violência sempre desempenhou grande papel nos negócios humanos, e qualquer pessoa que tenha se dedicado a estudar a história política não pode se manter indiferente ao papel que a violência desempenha na sociedade. A autora também acrescenta que a violência raramente foi escolhida como objeto principal de estudo e isso reforça o quanto foi considerada corriqueira e por sua vez, negligenciada, pois não há como questionar ou reivindicar aquilo que é óbvio e comum para todos.

Apesar de essa problemática ter se iniciado no discurso freudiano em 1913, em Totem e Tabu, podemos observar a pouca sistematização sobre essa temática no campo psicanalítico. Jurandir Freire Costa, em seu livro Violência e Psicanálise (2003) realiza elaborada crítica sobre a precarização de estudos sobre a violência ao longo do estudo psicanalítico. O autor ressalta que: "o uso da violência em psicanálise continua sendo confuso, impreciso e, às vezes, claramente estapafúrdio" 
(p. 12). Costa (2003) relembra que no ano de 1977 foi realizado um colóquio um Milão centrado no tema da violência; contudo, o resultado foi perturbador, uma vez que os psicanalistas em questão não tiveram o menor cuidado na sistematização, clareza ou coerência dos termos. Costa (2003) diz que a violência por muito tempo foi:

Tratada como tabu, cercado e protegido do pensamento, por uma aura romântico-pessimista, indicativa, talvez, de "nobreza intelectual"; ou é considerada o zero e o infinito da existência do sujeito, tornando-se uma espécie de categoria a priori irredutível a qualquer análise (p. 18).

Diante dessa falta de sistematização da violência na psicanálise, Pereira (2006) destaca que Freud muitas vezes utiliza diversas palavras que têm pequenas diferenças, sem apontar com precisão as reais características e os sentimentos entre elas, como: violência, crueldade, maldade, hostilidade, vingança, ódio, agressão e destruição.

Costa (2003) destaca três tópicos do discurso freudiano que se apresentam a interpretações genuínas ao longo da teoria freudiana sobre o papel da violência como fato essencial do psiquismo: a teoria do trauma infantil, em particular a teoria da sedução, a teoria da pulsão de morte e o totem e tabu.

Contudo, apesar da pouca estruturação do estudo da violência no campo psicanalítico, não podemos negar que esta esteve presente desde muito cedo na nossa história: segundo Fiori (2018), por meio do processo de evolução do homo sapiens a pesquisa antropológica e arqueológica demonstra evidências de que a "violência" originou-se nos primeiros primatas.

Assim, podemos dizer que a violência de forma individual e coletiva esteve presente em todo o caminho progressivo do homo sapiens. Segundo Birman (2009) a história humana é atravessada pela violência em todas as sociedades, ou seja, presente em diferentes tradições culturais, nos registros políticos, religiosos e simbólicos. Essa violência é característica fundamental da experiência social, uma vez que desregula e regula ao mesmo tempo as relações entre as subjetividades.

Dadoun (1998), afirma que a violência é característica crucial, básica e constitutiva do ser humano. Nesse sentido, o autor apresenta que o "Homo violens", é o sujeito determinado, composto, estruturado essencialmente pela violência. De acordo com o autor (1998): 
"Violência" vem do latim vis que significa "violência", mas também "força", "vigor", "potência"; vis designa mais precisamente o emprego da força", as "vias de fato", assim como a "essência" de um ser - o que solidifica nossa hipótese da violência como essência do homem (essência bem singular, na verdade, posto que "autodestrutiva" por vocação) (Dadoun, 1998, p.10).

Observando o percurso da violência e da guerra dentro da história, Birman (2009) nos deixa claro que: “a guerra está aí e isso é irrefutável. Não existe dúvida quanto a isso. Ela está em toda parte e cada vez mais presente na atualidade” (p. 131). O autor também afirma que a guerra foi considerada lugar-comum no Ocidente nos séculos XIX e XX, pois foi atravessada por diversos conflitos armados desde as guerras coloniais às revoluções - até duas violentas guerras mundiais. A barbárie se mostrou enfaticamente presente no que chamamos de modernidade.

A forma organizada que conhecemos como guerra - mas guerra é barbárie organizada e onde a violência é sistemática; a guerra entre tribos, etnias e nações só surgiu anos depois, junto com o surgimento dos primeiros grandes impérios e civilizações, com as fronteiras territoriais, por volta do terceiro milênio antes da "Era Cristã" (Fiori, 2018). Nesse sentido, podemos dizer que a guerra é um evento social, que exige da violência sistematização e organização e é administrada pela política. A guerra supera, portanto, sua especificidade destrutiva, agressiva em prol das questões políticas atinentes às unidades territoriais de poder e organização social, evidenciando os estados (Clausewitz, 1979; Farias, 2018). Segundo Farias (2018, p. 319), a guerra teria função estratégica na construção e expansão dos estados, ou seja, teria função primária e fundamental na formação e crescimento dos estados. Assim, os termos "guerra", "poder", “economia" e "território" seriam inseparáveis nas formações que criaram os estados. Birman (2009) sublinha a importância da tese de Clausewitz ao pensar sobre a relação da guerra e da política, pois afirma que a guerra é a continuação da política em outros termos, ou seja, há equivalência entre guerra e política e nas guerras através da história; o corpo feminino foi um dos mais prejudicados ao ser objetificado, violentado etc. O que, aliás, ocorreu e ocorre ainda em tempos de paz, ou pelo menos, de guerra não declarada oficialmente. Por isso, o estupro foi considerado um problema menor nos conflitos armados, porque a objetificação da mulher é estrutural na sociedade; o cenário só se alterou na guerra da Bósnia, em função dos excessos cometidos e do modo como foi utilizado como arma e como estratégia de guerra. 


\section{2}

\section{Percepção freudiana acerca da guerra}

Com o objetivo de dar continuidade ao nosso estudo, iremos analisar a guerra na história da psicanálise, destacando o quanto a guerra esteve na vida de Freud, que até a Primeira Guerra só conhecia esse evento por leituras.

Quando nos referimos à guerra, aos seus processos, às suas motivações e suas consequências, estamos tratando de uma questão extremamente complexa, e com inúmeras nuances. De acordo com o dicionário (Michaelis, 2019) o termo guerra que significa:

Luta armada entre nações, etnias diferentes ou partidos de uma mesma nação, por motivos territoriais, econômicos ou ideológicos; qualquer luta ou combate com ou sem armas; combate, conflito disputa; administração, negócios e burocracia militares; Hostilidade acirrada e oposição a alguém (p.1).

A problemática dessa luta com diversos interesses levou Freud a realizar muitos estudos em que aprofundou, à luz da psicanálise, as nuances da guerra, principalmente as motivações e inevitáveis consequências. É importante pontuarmos que algumas situações como a Primeira e a Segunda Guerras Mundiais perpassaram a vida de Freud e consequentemente impactaram de modo significativo seus estudos. O primeiro desses escritos sobre a guerra foi em $1915 \mathrm{e}$ recebeu o título Reflexões sobre o tempo de guerra e morte. Seu segundo trabalho sobre esse tema foi desenvolvido no ano de 1932, resultado de cartas trocadas com o físico Albert Einstein. Ambos os textos constituem as principais ideias produzidas por Freud acerca da guerra, apesar de em alguns pontos serem dissonantes entre si, devido à formulação da pulsão de morte em 1920, marco do prosseguimento de sua obra (Hamann, 2010).

Segundo Roudinesco (2016), para Freud o contexto de guerra e de morte no qual redigiu seu ensaio em 1915 revelava que a sociedade conduzida por aquela guerra teve perigosa desilusão, degradação do sentimento moral, assim como foi despertada para diversas formas de crueldade.

Roudinesco (2016) diz que Freud começava a perceber o quanto essa guerra representava um desejo de morte da própria espécie humana. A autora afirma que Freud não deixava o sujeito moderno esquecer que ele não passava de uma 
linhagem de assassinos, e que a guerra retornaria à arcaicidade pulsional, já descrita em Totem e Tabu.

Dessa forma, Freud (1915), em sua obra Considerações atuais sobre a guerra e a morte, esclarece que os impulsos pulsionais de natureza elementar consistem na essência mais profunda do homem, são semelhantes em todos os indivíduos que, por sua vez, buscam a satisfação destas necessidades originais. Nesse sentido podemos dizer que esses impulsos pulsionais primitivos, estão entre os impulsos que a comunidade tende a classificar como maus e, portanto, a proibilos: são os egoístas e os cruéis.

Freud (1915) complementa dizendo que o sujeito raramente é "bom" ou "mau" por inteiro e que normalmente possui algumas características "boas" e outras "ruins". Muitas vezes, quando criança, o sujeito tem forte aspecto "mau" e ao longo de sua trajetória até sua vida adulta, o sujeito pode se inclinar para o "bem".

Esses impulsos primitivos atravessam um distante caminho da infância até se tornarem ativos na fase adulta. De acordo com o autor, esses impulsos são: "Inibidos, desviados para outras metas e outros âmbitos, fundem-se uns com os outros, trocam seus objetos, dirigem-se em parte para a própria pessoa" (Freud, 1915/2010, p. 219). A busca da satisfação irrestrita das pulsões primitivas, tanto eróticas quanto agressivas, geraria o fim da sociedade humana. A fim de que isso não ocorra, o ser humano busca estabelecer pesadas renúncias pulsionais, que o sujeito aceita com o objetivo de preservar a possibilidade da vida em sociedade. $\mathrm{Ou}$ seja, há evidente necessidade de impor uma barreira, um freio às pulsões, o que é realizado por intermédio da educação (Pequeno, 2010). Pode-se dizer, então, que só foi possível formar a civilização por meio da renúncia às satisfações instituais primitivas de cada um dos sujeitos inseridos nela. As influências culturais, por sua vez, atuam de forma que as disposições egoístas se transformem em altruístas, sociais, pela adição de elementos eróticos. Contudo, é importante destacar que é raro um indivíduo ser completamente bom ou mau, ou seja, somente em determinadas circunstâncias e perspectivas o sujeito pode ser considerado bom ou mau (Freud, 1915).

É impossível para a cultura, através de qualquer instituição ou instância, erradicar os impulsos considerados primitivos e violentos do homem. Os impulsos pulsionais, são recalcados pela educação e continuam no inconsciente, em prontidão para aflorar quando obtiverem uma ocasião (Pequeno, 2010). Podemos 
observar que o fascismo narrado por Umberto Eco (2020), em seu livro Fascismo eterno, ilustra um cenário onde não apresentava uma filosofia própria, apenas uma retórica apresentando enorme contradição em seu vasto retalho de ideologias políticas e filosóficas. Essa cena nos deixa claro o quanto apesar de inicialmente confusa, a ideologia fascista se mostrou clara em sua prática com seu poder de destruição e devastação, principalmente quando decidiu se aliar ao nazismo. Assim, percebemos o quanto os impulsos pulsionais podem emergir quando tenham oportunidade.

Nessa retórica podemos dizer então que não há como extinguir o mal. Além disso, Freud (1915) complementa:

Portanto, também a transformação instintual em que se baseia nossa aptidão para a cultura pode ser desfeita - duradoura ou temporariamente - por interferências da vida. Não há dúvida de que a influência da guerra está entre os poderes capazes de produzir tal involução, e por isso não precisamos negar aptidão para cultura a todos aqueles que atualmente se conduzem de modo incivilizado, e podemos esperar que em tempos mais tranquilos se restabeleça o enobrecimento de seus instintos (p. 227).

Segundo Enriquez (1990), a civilização tem a função de fazer morrer nos indivíduos a natureza, isto é, a sociedade determina leis e estabelece o requisito primordial de amar o próximo como a si mesmo; portanto, essa exigência é responsável por tentar impedir a manifestação da agressividade em cada indivíduo, uma vez que determina amar tanto os amigos quanto os inimigos.

Isso quer dizer que existe um conflito no interior de cada sujeito, assim como na sociedade - isto é, nunca há paz, mas sim, forças em maior ou menor equilíbrio. Cada sujeito abrigaria em seu interior duas classes (de certo modo) antagônicas de pulsões. Mesmo no amor entre dois seres humanos existiria um componente sádico, agressivo (Pequeno, 2010). Freud (1915, p. 219) afirma que:

Formações reativas contra certos instintos criam a ilusão de uma mudança em seu conteúdo, como se o egoísmo se tornasse altruísmo e a crueldade, compaixão. Tais formações reativas são favorecidas pelo fato de que alguns impulsos instintuais aparecem em pares de opostos quase que desde o início, algo digno de nota e estranho para o conhecimento popular, denominado de "ambivalência afetiva". O mais fácil de observar e de apreender com a inteligência é o fato de o amor intenso e o ódio intenso surgirem com, muita frequência, unidos na mesma pessoa. A isso a psicanálise acrescenta que não é raro os dois impulsos afetivos tomarem a mesma pessoa por objeto.

Em relação às atitudes boas ou más, Freud (1915) destaca que há muito mais hipócritas na sociedade do que homens civilizados, ou seja, para o autor o sujeito 
só age bem em duas situações: quando suas tendências pulsionais o forçam a realizar ou quando essa conduta cultural beneficia o próprio sujeito.

Podemos notar que já em 1915 Freud em seus escritos talvez suspeitasse de uma força tão poderosa quanto a pulsão de morte. Quando observamos as cartas trocadas por Einstein e Freud denominadas Por que a guerra? em 1932, notamos que essa teoria já está presente em seu discurso, pois após 1920 Freud teria outros recursos (que não estavam disponíveis em 1915) para abarcar sua tese. Essas cartas foram uma sugestão do Comitê Permanente para a Literatura e as Artes da recémnascida Liga das Nações com o Instituto Internacional, devido ao objetivo de realizar uma Cooperação Intelectual. Essa proposta era a de que os principais intelectuais da época trocassem entre si a respeito de assuntos comuns à Liga das Nações (Monteiro, 2002; Hamann, 2010).

Assim, Albert Einstein deveria eleger um outro intelectual para dialogar sobre qualquer assunto de relevância internacional. Einstein, então, convocou Freud na esperança de que a psicanálise pudesse contribuir para o projeto de proteger a humanidade da maldição da guerra em direção à paz mundial (Oliveira \& Herzog, 2010). Nesse momento, Freud começa a se questionar e elaborar sobre a guerra e as motivações que levam os homens a engajar-se nela. Em sua resposta, Freud (1932) ressalta a surpresa expressa por Einstein pelo entusiasmo dos homens frente à guerra: “O senhor se admira de como é fácil mover os homens para a guerra, e supõe que haja alguma coisa neles, um instinto de ódio e destruição que favorece aquele incitamento. Mais uma vez concordo plenamente com o senhor. Nós acreditamos na existência de semelhante instinto" (p. 426)

Freud reintroduz seu conceito de pulsão, indicando que diferencia entre aquelas que tendem a unir e preservar (Eros) e as outras que tendem a destruir e matar. Assim, acrescenta o conceito como sendo uma das motivações humanas para a guerra, e que estaria além dos fatores históricos, sociais, políticos ou econômicos. Ressalta também que nenhum dos dois tipos de pulsão é menos essencial do que o outro e que é pouco provável que uma pulsão opere de maneira isolada (Oliveira \& Herzog, 2010). Freud destaca, então, que cada sujeito tem determinada razão que o leva para a guerra e entre tais razões com certeza está o desejo de agressão e destruição, pois a barbaridade que é encontrada ao longo a história da humanidade prova sua existência e potência. 
Freud (1932) prossegue afirmando que a pulsão de morte assume aspecto destrutivo, como veremos mais profundamente no decorrer do nosso estudo, em determinadas circunstâncias: "o instinto de morte torna-se instinto de destruição ao ser dirigido, com a ajuda de órgãos especiais, para fora, para os objetos. O ser vivo conserva sua vida ao destruir a alheia." (p. 429). Freud diz que uma parcela dessa pulsão continua viva no ser humano e busca-se derivar diversos fenômenos normais e patológicos para explicar a internalização da pulsão de destruição. O autor acrescenta ainda que uma grande justificativa biológica para esses impulsos perigosos que tentamos combater seria dizer que teríamos um efeito benéfico ao direcionarmos essa força pulsional para a destruição do mundo externo, pois dessa forma o sujeito estaria se preservando e destruindo a vida de outrem.

Diante desse cenário, Freud argumenta com Einstein no ano de 1932, sobre a motivação que levaria um homem a guerrear, tendo como base o conceito de pulsão de morte, elaborado em Além do princípio do prazer (1920); assim, Freud concorda com o cientista e diz que acredita na existência de uma pulsão de ódio e destruição que favorece aos homens o se deslocarem para a guerra.

Após 1920, Freud possuía já novos operadores conceituais em sua direção (ainda não estavam elaborados em 1915) para analisar a guerra e a motivação do homem frente a ela (Hamann, 2010). Segundo Enriquez (1990), a violência está presente na nossa sociedade e de modo algum pode desaparecer e sua função é gerar violência.

Para Freud (1932): "não há perspectiva de poder abolir as tendências agressivas do ser humano" (p. 429). Contudo, para Freud não seria necessário nem mesmo possível - abolir as tendências agressivas do sujeito, uma vez que poderia haver a possibilidade de desviá-las com a educação e a cultura a ponto de que não se manifestassem nas guerras. Nesse sentido, Arendt (1963/2000) acrescenta, como se a banalidade no mal proliferasse nos momentos em que a faculdade do pensar não conseguisse se manifestar, aprofundar e propagar.

Diante da impossibilidade da abolição total das pulsões agressivas, Freud reconheceu o quanto é evidente no percurso da história humana a presença da oposição entre a paz e a guerra, nos atravessando e nos modulando. A oscilação entre esses dois extremos seria expressão do jogo pelas pulsões de vida e de morte, presentes em diferentes proporções e arranjos nessa relação (Birman, 2009). 
Por fim, Freud (1932) questiona a Einstein o porquê de haver indignação por parte de tantas pessoas perante a guerra, e qual o motivo de simplesmente não aceitarem tal situação. Sua resposta a essa pergunta, se baseia no fato de que todos temos direito à vida, e a guerra é destruidora dos bens humanos:

A resposta seria: porque todo homem tem direito a sua própria vida, porque a guerra aniquila vidas humanas plenas de esperança, coloca o indivíduo em situações aviltantes, obriga-o a matar outros, algo que ele não quer, destrói preciosos bens materiais, resultantes do trabalho humano (p. 432).

Ressaltamos que apesar das divergências teóricas dos textos do Freud de 1915 e 1932, devido ao percurso histórico do autor, que no ano de 1932 nas cartas dirigidas a Albert Einstein, possuía mais arcabouço conceitual. Assim, além de retomar os argumentos utilizados no texto de 1915, o autor condiciona seu posicionamento à segunda teoria pulsional, trabalho realizado em além do princípio do prazer (1920), obra que orientou a investigação freudiana em direção ao tema da guerra e da violência (Birman, 2009). Para Costa (2003) no texto de 1915:

Freud refere-se ao "ódio" e aos "instintos maus e egoístas" do ser humano: Dentro de sua conhecida ótica evolucionista, procura mostrar que o homem, sem a ação da civilização, é instintivamente destrutivo, e a melhor prova seria o modo de vida dos povos "primitivos". "Era (primitivo) sem dúvida uma criatura muito impulsiva e mais cruel e maligna do que outros animais. Gostava de matar, e fazia isso como coisa natural. O instinto, que, segundo se diz, refreia outros animais de matar e devorar sua própria espécie, não precisa ser atribuído a ele (p. 29).

Costa (2003) acrescenta que no texto de 1920 Freud introduz o conceito de pulsão de morte e, a partir dela são incluídas noções como pulsões de domínio, pulsão de destruição, pulsão de agressão. A pulsão de morte, por sua vez, reorganiza a antiga divisão pulsional, priorizando no plano da vida psíquica a tendência à destruição do sujeito e do objeto.

Podemos dizer que o trabalho realizado em "além do princípio do prazer" (1920) permitiu a sofisticação de sua teoria, ou seja, de uma análise que começou em 1915 encontrando um marco em 1932. Em ambos há noções fortes e claras de violência na vida psíquica do sujeito - ligadas desde 1920 ao conceito de pulsão de morte - que sofrem a censura no processo da cultura, mas que se tornam nítidas nos conflitos bélicos (Hamann, 2010). Assim, é impossível falar do percurso da guerra 
em Freud sem mencionar a pulsão de morte, a pulsão de agressão e a pulsão de destruição.

A fim de tornarmos nosso estudo mais completo, em torno do uso do corpo da mulher como campo de batalha, nos próximos tópicos vamos nos debruçar sobre a pulsão de morte e suas derivações como pulsão de destruição e de agressão. Além disso, vamos também analisar a função objetalizante e desobjetalizante dentro desse cenário, pois apesar de opostas são também complementares.

\section{3}

\section{Pulsão de morte: agressão e destruição}

Freud ao longo de sua trajetória clínica formulou duas teorias pulsionais. A primeira já estava implícita desde os "Três ensaios da sexualidade" (1905), onde fazia o contraponto das pulsões sexuais com aquilo que nomeava de: "necessidades" (ou "funções de importância vital"), mostrando como as primeiras nasciam apoiando-se nas segundas e depois divergiam, particularmente no autoerotismo" (Laplanche \& Pontalis, 1982/2016, p. 416). Somente no seu escrito “A concepção psicanalítica da perturbação psicogênica da visão" (1910), é que Freud classifica essas "grandes necessidades" apontadas anteriormente como contrárias às pulsões sexuais, como "pulsão de autoconservação", se referindo também como pulsão do ego, sendo posta a serviço do mesmo com o objetivo de defendê-lo. Nesse sentido, diante de uma perspectiva biológica, podemos dizer que havia contraposição entre as pulsões: as que deveriam conservar o indivíduo (pulsão de autoconservação) e aquelas que estavam a serviço dos fins da espécie (Laplanche \& Pontalis, 1982/2016).

Em seu trabalho introdução ao narcisismo (1914), essa contraposição entre pulsão sexual e pulsão de autoconservação começou a apresentar inconsistências, pois o eu passou a ser marcado como erotizado, sendo o primeiro objeto investido pela libido (Hamann, 2010). Segundo Laplanche e Pontalis (1982/2016):

A introdução da noção de narcisismo não faz caducar imediatamente para Freud a oposição entre pulsões sexuais e pulsões de ego, mas introduz nela uma distinção suplementar; as pulsões sexuais podem fazer incidir a sua energia num objeto exterior (libido objetal) ou no ego (libido do ego ou libido narcísica). (...) A oposição libido do ego-libido objetal irá, no pensamento de Freud, retirar rapidamente todo o seu interesse à oposição pulsões de ego-pulsões sexuais (p. 418-419). 
Após a formulação da "introdução ao narcisismo" (1914), no ano de 1920 Freud formula a segunda teoria pulsional, em seu texto "além do princípio do prazer", sendo considerado um divisor de águas no percurso psicanalítico. A grande diferença nessa nova teoria pulsional é a elaboração de uma nova dualidade, uma vez que a pulsão sexual e a pulsão do eu, apesar de não serem idênticas, não mais se mostravam contrárias. A pulsão de vida e a pulsão de morte, por sua vez, apresentavam mais solidez em sua dualidade. Sobre essa nova dualidade entre pulsão de vida e pulsão de morte, Freud (1920) esclarece que: "Desde o princípio nossa concepção era dualista, e hoje é mais claramente dualista do que antes, desde que não mais denominamos os opostos 'instinto do Eu' e 'instintos sexuais', mas instinto de vida e de morte" (p. 234).

A pulsão de vida, por sua vez, agora agrupando as pulsões sexuais e de autoconservação, também qualificadas de "Eros", tem como objetivo preservar os elementos vitais presentes, como produzir, a partir desses elementos mais globalizantes (Laplanche \& Pontalis, 1982/2016). Ressalta-se que essa elaboração da pulsão de vida, consiste no agrupamento das já conhecidas pulsão de autoconservação e pulsão sexual, já que: “essas pulsões diziam respeito às excitações que introduziam a busca de objetos" (Azevedo \& Neto, 2015, p. 70). Nesse sentido, Freud (2010/1920) afirma que:

O instinto sexual transformou-se para nós em Eros, que busca impelir uma para outra e manter juntas as partes da substância viva, e os comumente chamados de sexuais apareceram como a porção desse Eros voltada para o objeto. Segundo nossa especulação, esse Eros atua desde o começo da vida e surge como "instinto de vida", oposto ao "instinto de morte", que se originou pela animação do inorgânico (p. 235).

Freud pontua que a pulsão de morte está baseada inicialmente em considerações especulativas e que foi aos poucos se impondo a ele. Essa pulsão, por sua vez, desenvolvida em contraponto à pulsão de vida, se refere principalmente a uma: "redução completa das tensões, isto é, tendem a reconduzir o ser vivo ao estado anorgânico" (Laplanche \& Pontalis, 1982/2016, p. 407). Ou seja, inicialmente essa força de destruição seria voltada para o interior do sujeito e posteriormente direcionada para o exterior, sendo manifestada sob forma de pulsão de agressão ou de destruição, como veremos ao longo do nosso estudo (Laplanche \& Pontalis, 1982/2016). 
Assim, Laplanche e Pontalis ressaltam três principais motivos evidentes que levaram Freud a desenvolver a pulsão de morte. O primeiro deles é a formulação da compulsão à repetição, um processo em que o indivíduo se posiciona ativamente em cenários dolorosos, repetindo experiências anteriores sem se lembrar do protótipo. Assim, podemos dizer que a pulsão de morte atua em relação ao próprio sujeito por meio da compulsão à repetição, marcada por seu traço conservador e a tendência de retornar a um estágio anorgânico a partir da destruição de Eros (Arantes, 2011).

A segunda clara razão que levou Freud a elaborar a teoria da pulsão de morte se dá na importância de abarcar noções de ambivalência, agressividade, sadismo e masoquismo. O terceiro e último motivo apontado pelos autores foi a necessidade de Freud de abarcar o ódio em um cenário diferente da pulsão sexual, dado que não via possível tal relação entre ambos. É necessário destacar que a pulsão de vida e a pulsão de morte não podem ser separadas uma da outra. A vida do sujeito se dá no balanceamento tanto da pulsão de vida, quanto da pulsão de morte. Ou seja, tanto do ligamento do sujeito com o objeto quanto do desligamento com o mesmo.

Percebemos o quanto a pulsão de morte é necessária para pensarmos o processo do estupro como arma de guerra, uma vez que a agressividade é um elemento evidente nesse cenário e formulado a partir da pulsão de morte voltada para o exterior. Não podemos deixar de sublinhar o quanto a pulsão de morte é necessária para que haja a sobrevivência e consequentemente a vida; contudo neste estudo, ao analisar os tópicos que envolvem o estupro como arma de guerra, estamos nos aprofundando nos aspectos agressivos e destrutivos da pulsão de morte, pois é cruelmente retirado da mulher o direito de decisão sobre o seu próprio corpo e sua subjetividade é anulada, no momento em que a mulher é brutalmente violentada, seu corpo é usado meramente como uma arma de guerra e muitas vezes obrigada a carregar um filho fruto do estupro.

Segundo o dicionário Michaelis (2020) agressividade significa: "qualidade de ser agressivo, disposição para ser violento ou para agredir, estado caracterizado por comportamento hostil, violento e destrutivo" (p.1). A pulsão de agressão, segundo Laplanche e Pontalis (1982/2016) se refere à pulsão de morte direcionada para o exterior, com o fim de destruir o objeto. A noção de pulsão de agressão foi formulada por Adler em 3 de junho de 1908 e recusada por Freud durante muito tempo. Contudo, antes do "além do princípio do prazer" (1920) e da proposta da 
pulsão de morte, a agressividade se mostrava presente em sua obra (Laplanche \& Pontalis, 1982/2016).

Antes da proposta de Adler, em os "três ensaios sobre a teoria da sexualidade" (1905) a agressividade estava presente. O sadismo é descrito nesse texto como elemento agressivo mecanizado e exagerado da pulsão sexual. Destacamos o quanto nessa primeira teoria das pulsões, a agressividade estava ligada à sexualidade e o quanto Freud apresentava resistência em formular a ideia da pulsão de agressão separada da libido (Hamann, 2010). Segundo Birman (2006), apesar de Freud ter apresentado resistência para assumir a pulsão de agressividade em sua teoria, esse conceito já se evidenciava em sua obra:

A problemática da agressividade enunciou-se desde os primórdios no discurso freudiano. Assim, na "Psicoterapia da histeria", de 1895, essa problemática já se enunciara, pelo viés da questão da resistência, no registro estritamente clínico. Porém, nas experiências analíticas de Dora e do pequeno Hans, a agressividade foi inscrita no registro do sintoma, sendo então responsável pela produção e pela reprodução deste (Birman, 2006, p. $362)$.

Foram necessários dez anos para que Freud elaborasse a noção de agressividade independente da libido, pois foi preciso que estruturasse uma pulsão que fosse contrária à pulsão sexual e de autoconservação para que pudesse encaixar a pulsão de agressividade. Assim, construiu ao longo de sua obra a pulsão de morte. Desse modo, a combinação entre a pulsão de agressão e a pulsão de morte dirigiu a uma aproximação entre o dualismo Eros-pulsão de morte e o dualismo sexualidade-agressividade. A agressividade, por sua vez, se constituiu numa nova teoria (Hamann, 2010). Após a virada de 1920, a noção de agressividade tomou outro rumo, um lugar mais fundamental no discurso freudiano. $\mathrm{O}$ dualismo entre pulsão de vida e pulsão de morte mostrou um novo caminho teórico: a agressividade. Nas contribuições de "além do princípio do prazer" (1920), "O eu e o id" (1923), "o problema econômico do masoquismo" (1924) e "o mal-estar na civilização" (1930) esse marco fica mais evidente (Birman, 2006).

Dentre essas obras, em “Além do princípio do prazer”, escrito em 1920, os conceitos de destrutividade e de pulsão de morte se relacionam com a noção de agressividade - seja direcionada ao outro ou ao próprio sujeito. Muitos psicanalistas atribuem assim à pulsão de morte um papel fundamental na determinação das guerras e outros atos violentos coletivos, conforme Oliveira \& Herzog (2010) fazem 
questão de destacar. Tanto as noções de agressividade quanto a de destrutividade podem ser designadas como a pulsão de morte voltada para o exterior. Percebe-se um problema de difícil diferenciação dos termos. Hamann (2010) a fim de distinguir tais termos, afirma que a agressividade não está só voltada para a destruição do objeto, está também nas diferentes relações estabelecidas no aparelho psíquico, principalmente no supereu. Podemos notar essa questão no seu texto "o eu e o id" onde Freud (1923) afirma que: “É notável que o homem, quanto mais restringe sua agressividade ao exterior, mais severo, mais agressivo se torna em seu ideal do eu" (p. 68).

Em "o mal-estar na civilização", Freud coloca o conceito de pulsão de destruição no sentido da manifestação da agressividade, onde o sujeito não seria brando e cheio de amor como gostaríamos de imaginar, mas sim composto de forte agressividade. $\mathrm{O}$ autor afirma que:

O que de realidade por trás disso, que as pessoas gostam de negar, é que o ser humano não é uma criatura branda, ávida de amor, que no máximo pode se defender, quando atacado, mas sim que ele deve incluir entre seus dotes instintuais, também um forte quinhão de agressividade (1930/2010, p.76).

Dessa forma, para Enriquez (1990), a civilização tem a função de fazer "morrer" nos indivíduos a natureza, isto é: “A civilização impõe proibições e estabelece como exigência fundamental amar ao próximo como a si mesmo, logo, amar tanto os inimigos quanto os amigos, pois ela deve impedir a manifestação da agressividade que jaz no coração de cada pessoa" (p. 108). Diante dessa problemática, a psicanálise acredita que existe um conflito no interior de cada sujeito, assim como na sociedade - isto é, nunca há paz, mas sim, forças em conflito. Cada sujeito abrigaria em seu interior duas classes (de certo modo) antagônicas de pulsões. Mesmo no amor entre dois seres humanos, existiria um componente sádico, agressivo (Pequeno, 2010).

Dentro dessa elaboração complexa, podemos dizer que a agressividade é resultado da expulsão da pulsão de morte para o exterior. Assim, cada indivíduo preserva sua própria vida, destruindo a alheia. $\mathrm{Na}$ destruição do outro, existe uma função pulsional, e isso ocorre tanto nos sujeitos quanto nas nações (Pequeno, 2010). Além disso, apesar da educação por meio da cultura e do ambiente contribuir para a mudança instintual a fim de transformar o egoísmo em altruísmo, é impossível extinguir todo o mal existente no indivíduo e na sociedade. Para 
Winograd (2019), não existe a perspectiva de que as tendências agressivas sejam abolidas no ser humano: não há como extirpar o mal nem mesmo com a atuação da educação e da cultura. Já dizia Freud (1915) que, na sociedade, há um número muito maior de hipócritas do que homens realmente civilizados.

Segundo Laplanche e Pontalis (2016) tanto a pulsão de destruição quanto a pulsão de agressão podem ser descritas como a pulsão de morte voltada para o exterior. Assim, a ideia de destruição em Freud está ligada a uma "tendência à destruição do objeto, ligada a sentimentos de ódio e hostilidade" (Hamann, 2010, p. 37).

Em 1917, em seu texto sobre a melancolia, Freud faz referência pela primeira vez à destruição direcionada ao próprio sujeito e questiona como o eu pode se autodestruir:

Nós percebemos, como o estado primordial de onde parte a vida instintual, um tão formidável amor do Eu a si próprio, vemos liberar-se, na angústia gerada pela ameaça à vida, um tal montante de libido narcísica, que não entendemos como esse Eu pode consentir na sua própria destruição (p.185).

É notável o quanto os escritos do Freud sobre a guerra fazem referência a destrutividade e ao ódio como forças direcionadas para o exterior. O texto de 1915 , por exemplo, em "considerações atuais sobre a guerra e a morte", analisa o quanto a guerra é responsável por despir os níveis mais profundos da cultura, e faz nítido o homem primitivo que há em todos nós, responsável pelo horror da guerra. Em 1920, em “além do princípio do prazer" Freud introduz o conceito de pulsão de morte que é, em um primeiro momento, direcionado para o interior e pendendo à autodestruição e em um segundo momento para o exterior, se apresentando sob forma da pulsão de agressão ou destruição (Laplanche \& Pontalis, 2016).

No "Eu e o Id" (1923) no capítulo destinado à análise das duas classes de pulsões, Freud se questiona sobre a dualidade e a disjunção das pulsões, uma vez que até aquele momento a pulsão de vida e a pulsão de morte se mostravam opostas em suas funções. Nesse sentido, o autor afirma que: “o instinto de destruição é habitualmente posto a serviço de Eros para fins de descarga" (p. 52). Dessa forma, observamos que com o objetivo de preservar a vida, o sujeito direciona para o exterior sua parcela destrutiva. Freud, por sua vez, acrescenta que: "Nós temos dificuldade em achar uma representação para Eros, mas ficamos satisfeitos em 
poder encontrar no instinto de destruição, para o qual aponta o ódio, um representante do instinto de morte, de tão difícil apreensão" (p. 53).

Observando essas afirmações sobre a pulsão de destruição, podemos perceber o quanto está presente no cenário de guerra, principalmente no que estamos nos propondo a investigar, onde o homem soldado usa o corpo da mulher sem sua permissão, aniquilando sua identidade, vontade, desejo e transformando seu corpo em mero objeto estratégico de guerra e procriação.

\section{4}

\section{A desobjetalização e a objetalização do corpo da mulher}

Analisamos até o momento fatores como a violência, a pulsão de morte, a pulsão de agressão e a pulsão de destruição que são elementos presentes no cenário de guerra onde a mulher deixa de ser vista como um sujeito próprio de desejos, sua singularidade é completamente anulada e seu corpo passa a ser um campo de batalha, uma vez que é usado como ferramenta de guerra sem seu consentimento e contra seu desejo.

André Green (1988) propõe dois conceitos que serão altamente necessários para compreendermos esse cenário em que a mulher tem seu corpo usado como arma de guerra. Esses conceitos são: a desobjetalização e a objetalização. Ambos são importantes para analisarmos a relação entre pulsão e objeto. Para o autor o objetivo principal da pulsão de vida é garantir uma função objetalizante, pois acredita que podem coexistir os mecanismos de ligamento e desligamento. Assim, essa função não expressa apenas a criação de uma relação com o objeto (interno ou externo), mas também a sua capacidade da criação de objetos mesmo quando não estão presentes.

Dessa forma, André Green (1988) não acredita que a pulsão de morte atue apenas pelo desligamento. A função desobjetalizante, para o autor, ataca as ligações com o objeto e com todos os substitutos dele, com o objetivo de desfazer as relações presentes (Oliveira, 2014). É necessário destacar que não somente o objeto é atacado como também: "todos os substitutos deste - o eu, por exemplo, e o próprio investimento à medida que sofreu o processo de objetalização" (Green, 1988, p. $60)$, atuando ainda na própria atividade potencial de investir. 
Assim, podemos dizer que além de ser combustível dos vetores de investimento nos objetos, a pulsão de vida também alteraria as estruturas em objetos de investimento. Nesse sentido, segundo Oliveira, Winograd e Fortes (2016): "além de operar as ligações, as pulsões de vida seriam o próprio princípio de investimento, o próprio movimento de investir” (p. 76). Segundo as autoras, as pulsões de morte, por sua vez, seriam presentadas pela função desobjetalizante que teria como função atacar o objeto e seus substitutos, desligando as ligações existentes, e assim agredindo a própria atividade potencial de investir. Simbolizaria, dessa maneira, o princípio do desinvestimento.

Nesse sentido, ao analisarmos a função objetalizante, é possível considerar que, além de as funções psíquicas serem classificadas como objetos, toda e qualquer função do próprio sujeito também o é. O narcisismo negativo por sua vez é uma expressão da função desobjetalizante; sua manifestação clínica - expressa pela pulsão de morte - é a pulsão que busca a volta ao estado anterior, ao nada, ao estado de desligamento (Green, 1993, 1990, 2002, 2011; Falcão, 2014). Green (1988) acrescenta que o Narcisismo negativo se daria então por uma "expressão de uma função desobjetalizante que não se contentaria em recair sobre os próprios objetivos ou seus substitutos, mas sobre o próprio processo objetalizante" (Green, 1988, p. 61) Assim, segundo Falcão (2014):

A morte na vida se instala e se executa, silenciando e paralisando a libido, que deixa de se locomover no aparelho psíquico, impedida assim de circular num vaivém com o outro. Narcisismo de morte é morte na não vida. É a não constituição psíquica (Falcão, 2014, p. 48).

No conflito armado da ex-Iugoslávia, mais especificamente na guerra da Bósnia, o corpo da mulher ao mesmo tempo em que foi submetido a objetalização também foi desobjetalizado e consequentemente dessubjetificado. Nesse sentido, podemos dizer que o corpo da mulher foi objetalizado como uma munição de combate, com um propósito maior e coletivo, a guerra. Foi altamente desobjetalizado, uma vez que a mulher foi extremamente desinvestida como sujeito alteritário, agredida, incapaz de decidir sobre o destino do seu próprio corpo e dessubjetivado, pois foi subjugada a grande esvaziamento provocado pelo estupro e pelo uso do seu corpo como objeto. Além disso, podemos considerar nesse cenário uma grande expressão do narcisismo negativo, uma vez que há intensa busca da pulsão de morte pelo desligamento, recaindo pela pulsão objetalizante e havendo 
em grande escala esvaziamento da subjetividade do sujeito e consequentemente sua morte psíquica e subjetiva em vida.

Assim, observamos o quanto essas experiências podem ser traumáticas, visto que podem violentar abruptamente com um estado de esferas do psiquismo, causando desorganização nas funções habituais trazendo graves consequências para o sujeito e sua organização psíquica (Rudge, 2009). Dessa forma, vamos explorar no próximo capítulo, sob a ótica da psicanálise, o trauma e seus efeitos para a mulher que é brutalmente agredida, tratada como objeto e despojada de seus direitos de escolha quanto a seu próprio corpo. 


\section{3}

\section{Estupro, trauma e guerra}

Como vimos ao longo do nosso estudo, o estupro na guerra foi considerado por muito tempo como subproduto desses conflitos. Contudo, na guerra da Bósnia, esse cenário mudou e o estupro não foi mais considerado mera consequência da guerra, e sim uma estratégia de guerra. Nessa cruel cena, a mulher é anulada como sujeito, seu desejo é invalidado junto com qualquer possibilidade de consentimento. Contra sua vontade, o corpo da mulher é usado como munição de guerra com o fim de um propósito maior. Analisamos que esse cenário no qual a mulher é anulada, estuprada e usada como finalidade maior de guerra é circunstância potencialmente traumática.

\section{1}

\section{Conceito de trauma na obra freudiana}

É de fundamental importância nos atermos cronologicamente aos tempos do trauma ao longo da obra de Freud; para isso, neste primeiro momento nos apoiaremos nos três grandes períodos do trauma na teoria freudiana. Assim, poderemos posteriormente compreender o trauma proeminente no cenário onde a mulher é usada meramente como um corpo-objeto, como arma dessubjetivante com o poder de esvaziamento do sujeito.

Bokanowski $(2002,2005)$ propõe três momentos do trauma na teoria freudiana, que podem ser aproximados dos seguintes casos clínicos: histeria, neuroses traumáticas e sofrimentos narcísico-identitários (Winograd, Klautau \& Sollero-de-Campos, 2014). O primeiro tempo foi "traumatismo", entre 1895-1920, com o protótipo do a posteriori; seguido pelo "traumático" em 1920, que tem o modelo econômico como proposta e, por fim, o "trauma" em 1939 com o modelo narcísico. Segundo Bokanowski (2005), o termo "traumatismo" deve ser limitado para denominar um nível de desorganização referente ao processo secundário, do $a$ posteriori, articulado com o traumatismo sexual da teoria freudiana da "sedução". O termo "trauma" propriamente dito, de acordo com o autor, seria mais acertado para traduzir a lógica traumática precoce e arcaica, na qual tivesse havido comprometimento dos investimentos narcísicos e, consequentemente, da formação do ego. Por fim, o termo "traumático" seria uma expressão que poderia descrever uma forma de funcionamento psíquico semelhante às duas categorias anteriormente 
mencionadas, vinculado àquilo que caracteriza uma situação traumática, independentemente do estágio da vida psíquica ou da circunstância. Neste capítulo não iremos aprofundar a discussão do trauma narcísico, por considerarmos que o trauma a posteriori tem fundamental importância para a fundação da teoria psicanalítica e, no econômico, por se aproximar estritamente do nosso tema estudado. Apesar da importante contribuição de Bokanowski, não vamos nos deter na definição da nomenclatura das palavras traumatismo, trauma e traumático.

O primeiro momento da teoria do trauma se situa entre 1895 e 1920, onde é relacionado com o sexual e a teoria da sedução, constituindo assim o modelo do $a$ posteriori (Freud, 1895/2016). Esse primeiro momento da teoria do trauma pode ser explorado em dois períodos fundamentais. No primeiro, situado entre 1895 e 1900-1905, Freud conceituou o modelo do a posteriori diretamente ligado à teoria da sedução, no qual a criança teria sofrido um atentado sexual perverso por parte de um adulto do sexo masculino. Para o autor, o trauma estaria localizado nessa cena, não registrada pela criança como um evento traumático, e se manifestando em dois tempos. O primeiro tempo ocorre na cena da sedução, na qual a criança é investida sexualmente por parte de um adulto, sem originar qualquer excitação sexual. O segundo tempo, anos depois do primeiro ocorrido, seria outra situação a princípio, inócua - que se associaria a ele, desvelando o fator traumático de todo o cenário. Ou seja, é neste segundo tempo que o trauma eclode (Oliveira, 2014).

Em 1897, a partir de seus novos questionamentos e estudos sobre a histeria, Freud assinalou que a sedução não seria mais o fator original para o desencadeamento do trauma, pois concluiu ser improvável que todos os pais fossem pervertidos. Estipula então a "fantasia", expressão do desejo, como o principal novo componente para o trauma.

No período de 1905 a 1920, baseado em suas novas descobertas, Freud reformula a teoria da sedução e modifica sua hipótese sobre o desenvolvimento infantil. Neste novo cenário em que vigora a fantasia, observa que há possibilidade da existência de uma sexualidade infantil, direcionada principalmente para os progenitores ou figuras parentais, que se constituem frequentemente como os primeiros objetos de afeto e desejo da criança (Bokanowski, 2005; Rudge, 2009).

O segundo momento da teoria do trauma, iniciado em 1920, é marcado pela concepção metafórica do modelo econômico do aparato psíquico. Como é realizado em Além do princípio do prazer, o aparelho psíquico apreende a compulsão à 
repetição como forma de funcionamento frente a uma perturbação traumática (Freud, 1920; Oliveira, 2014). Por fim, o terceiro momento da teoria do trauma é o modelo construído no ano de 1939 em Moisés e o Monoteísmo. Nesse momento, Freud sustenta que a origem traumática das neuroses seria composta por um investimento narcísico mais precoce na formação do self (Freud, 1939; Oliveira, 2014).

\subsection{1}

\section{O primeiro contato com o trauma}

A fim de entendermos as consequências traumáticas para os sujeitos comprometidos nesse cenário, julgamos necessário compreender o percurso da teoria do trauma no campo psicanalítico e posteriormente analisar o conceito de trauma em psicanálise.

O estudo sistemático da perturbação hoje conhecida como Transtorno do Estresse Pós-Traumático, surgiu a partir de rigoroso critério de diagnóstico definido anteriormente por Charcot, Freud e Janet (Kapczinski \& Margis, 2003). Estes autores foram os primeiros a aprofundar os estudos relativos às consequências emocionais do trauma psíquico.

O termo "neurose traumática" foi utilizado originalmente pelo médico neurologista alemão Hermann Oppenheim em 1889, para indicar perturbações nervosas que apareciam devido a catástrofes, como graves eventualidades em linhas ferroviárias. Oppenheim percebia diferença entre os quadros da histeria e os da neurose traumática, uma vez que acreditava que nesta última havia dolorosos sentimentos depressivos que não havia na histeria (Rudge, 2009). Destacamos que muitos anos antes, no período de 1796-1881 o psiquiatra francês Pierre Briquet estabelecera a primeira conexão psicológica entre os sintomas de histeria e fenômenos "sociológicos" ou "materiais", como por exemplo: condições de vida, trabalho, fases da natureza e até mesmo movimentos dos astros. O surgimento da sociedade industrial (principalmente da grande quantidade de estações ferroviárias, com volumoso número de acidentes graves traumáticos, que principalmente lesionava os homens) inaugurou ampla discussão sobre a histeria masculina (Roudinesco \& Plon, 1998).

Charcot em 1887 conduziu inúmeros estudos sobre a histeria e analisou também a relação psicológica entre os "chocs nerveux" induzidos por força de 
ocorrências externas, e aqueles induzidos por sugestão hipnótica. Dos seus quatro discípulos mais famosos, dois deles, Pierre Janet e Sigmund Freud, foram na direção de aperfeiçoamento dos insights sobre as instâncias emocionais das situações traumáticas e de sua relação com a histeria (Schestatsky et al., 2003). Janet, em 1887, iniciou sua escrita sobre os mecanismos de dissociação, trauma e histeria. No período de 1889 a 1920 já havia atendido um total de 591 pacientes. Em 297 deles, encontrou origens traumáticas para suas psicopatologias. Assim, Janet criou o termo "subconsciente" para descrever o conjunto de memórias que formariam os esquemas mentais que ordenariam e guiariam a relação dos indivíduos com seu meio ambiente. Propôs, então, que quando as pessoas experimentavam "emoções veementes", suas mentes se mostravam incapacitadas de parear as experiências aterrorizantes com os esquemas cognitivos prévios, “subconscientes" (Ellenberger, 1970; Van Der Hart \& Friedman, 1989).

Dessa forma, a memória da experiência traumática não conseguia ser integrada na consciência e permanecia dissociada. Janet formulou, assim, a primeira compreensão mais abrangente do efeito do trauma sobre a mente, baseada na noção, bastante contemporânea, de que um estado de excitação extrema poderia causar o fracasso na integração da memória traumática com a consciência. O resquício de memória do evento traumático permaneceria inconsciente, como uma "ideia fixa", ou seja, que não poderia ser "eliminada" enquanto não fosse transcrita dentro da conjuntura da narrativa pessoal do paciente que sofreu o evento traumático. Enquanto isso não ocorresse, a memória do trauma continuaria a se "intrometer" na consciência como percepção excessiva de terror, preocupação obsessiva e reexperimentação somática sob a forma de reação ansiosa (Schestatsky et al., 2003).

Tal como Charcot, Freud (1893) começou seus estudos baseando-se inicialmente na neurologia. Contudo, posteriormente percorreu caminhos que lhe permitiram criar a psicanálise. Desse modo, a partir da análise com as histéricas, ele explorou uma trajetória na qual conseguiu investigar o trauma psíquico (Schestatsky et al., 2003). Não podemos deixar de evidenciar que no início da psicanálise trauma e histeria eram termos inseparáveis. Charcot se dedicava em suas pesquisas às paralisias traumáticas, que eram resultantes de lesões no sistema nervoso provocadas por acidentes. Assim, Charcot diferenciou as paralisias orgânicas das paralisias histéricas, julgando que somente nas orgânicas existiria uma lesão anatômica, elemento do sistema nervoso. Freud, por sua vez, destinou 
um artigo inteiro com o propósito de distinguir essa particularidade entre os termos. Evidenciou que as paralisias orgânicas atingiam o sistema nervoso, enquanto as paralisias histéricas respeitavam a concepção popular do corpo e de suas partes e não a lógica científica dos neurologistas (Uchitel, 2011).

Freud acentua que até 1886 , o termo histeria não poderia ser considerado bem definido, pois era caracterizado, naquela época, apenas por "sinais negativos". A doença histérica necessita da irritação genital, e que nenhuma outra sintomatologia poderia ser atribuída à histeria, pois poderia haver a combinação de sintomas e, por fim, a exagerada importância à simulação no quadro clínico da histeria. Além disso, Freud sublinha o quanto a mulher histérica, durante muitas décadas, era considerada uma simuladora, muitas vezes julgada e até mesmo condenada como "feiticeira" ou "possuída pelo demônio" (Freud, 1886). Freud pontua o quanto Charcot, em seu estudo da histeria, estudou os casos que considerava tipos perfeitos da doença; começou, dessa forma, a conter a relação existente entre neurose e o sistema genital a suas proporções corretas, validando a desconhecida frequência dos casos de histeria masculina, principalmente de histeria traumática. Freud por sua vez, define histeria traumática como:

Nas neuroses traumáticas, não é o ferimento físico insignificante a causa efetiva da doença, mas o afeto de pavor, o trauma psíquico. De maneira análoga, para muitos, senão para maioria dos sintomas histéricos, nossas investigações revelaram causas imediatas que devemos designar como traumas psíquicos. Toda vivência que suscita os penosos afetos de pavor, angústia, vergonha, dor psíquica, pode atuar como trauma psíquico (Freud, 1893/2016, p.22).

A histeria traumática, por sua parte, tem como principal causador o fator acidental; assim, a emergência do quadro histérico e seus ataques, são a reprodução do acontecimento traumático. Dessa forma, o trauma não é causado por nenhuma lesão, mas sim por um susto, uma surpresa que converte o episódio em trauma psíquico (Uchitel, 2011).

Com o intuito de diferenciar as histerias, podemos dizer que a histeria traumática é um evento traumático importante e que deve ser considerado, principalmente o afeto de pavor e o de susto que estão por trás desse acontecimento, enquanto na histeria comum é uma série de impressões afetivas que devem ser assinaladas (Laplanche \& Pontalis, 2016). 
Freud (1892/1996) em seu texto sobre a teoria dos ataques histéricos sublinha a importância do retorno da lembrança, normalmente a mesma recordação, alucinatória para o desencadeamento de um ataque histérico, ou seja, não é considerada uma lembrança qualquer: é sim potencialmente forte para causar um ataque histérico - um trauma psíquico. Essa lembrança permanece inconsciente para o sujeito, isto é, recalcado e fora do alcance da consciência. Observa-se, contudo, o quanto a lembrança inconsciente traumática é um fator fundamental para o surgimento da histeria e um aspecto presente no ataque histérico (Freud 1892/1996; Favero, 2009).

Podemos dizer então, que trauma psíquico, segundo uma concepção freudiana, pode ser definido como: "impressão ou vivência que provoque afetos penosos de medo, angústia, vergonha ou dor psíquica que o sistema nervoso tem dificuldade para resolver por meio do pensamento associativo ou por uma reação motora." (Uchitel, 2011, p.33). Dessa maneira, como nos indica esta autora, esse primeiro contato com o trauma é marcado pelo método catártico, que por meio da hipnose e da sugestão recupera a recordação traumática com a ab-reação e os afetos ligados a ela (Uchitel, 2011).

Ab-reação foi um termo utilizado pela primeira vez em Comunicação preliminar (Freud \& Breuer, 1893) para indicar um processo de efeito catártico no sujeito, assim produzindo uma descarga emocional e a liberação do afeto ligado à recordação de um fato traumático. Nesse sentido, podemos dizer que a ab-reação é a primeira ferramenta que permite que o sujeito reaja a situações traumáticas e evita que ele preserve afeto ligado a esse acontecimento. Contudo, essa reação precisa ser "adequada" para que tenha o efeito catártico (Laplanche \& Pontalis, 1982/2016; Roudinesco \& Plon, 1998).

Um cenário importante que não podemos deixar de nos questionar é sobre a possibilidade de uma ausência da ab-reação. Nessa circunstância, a escassez da abreação pode estar relacionada com o trauma, uma vez que não há essa descarga de afeto ligada à lembrança traumática, permanecendo assim um afeto estrangulado, de forma que há dissociação de ideias equivalente a ele na consciência (Freud, 1893; Favero, 2009). Assim, podemos dizer que o afeto é estrangulado, segundo Rudge, quando um (2009):

fato traumático acontece na vida do histérico e sua lembrança é dissociada do conjunto de suas memórias, formando um segundo grupo psíquico. Tal 
fato, quando ocorreu, foi de modo a provocar emoções muito intensas, como a raiva, a vergonha ou a angústia; mas como essas emoções não puderam ser expressas no momento certo de forma normal, as ideias que compunham a memória do fato ficaram dissociadas do conjunto das outras ideias. A partir daí, a ideia dissociada, carregando um "afeto estrangulado" passa a ser um corpo estranho no psiquismo provocando expressões de emoções anômalas como as que se manifestavam no ataque histérico (Rudge, 2009, p.16).

Nesse cenário traumático, o sujeito é incapaz de lidar com alguma reação que lhe possibilitasse descarregar os afetos trazidos pelo momento (Favero,2009). Dessa forma, é possível dizer que certa ideia se tornou patológica, quando há a cisão psíquica e ela se comporta como um corpo estranho no psiquismo (Rudge, 2009).

Assim, antes da criação do método psicanalítico, e por sua vez, da associação livre, a hipnose e a ab-reação, eram as ferramentas utilizadas que possibilitavam trazer à consciência as ideias dissociadas presentes no psiquismo. $\mathrm{O}$ trauma segue realizando efeito no psiquismo como se estivesse presente, característica crucial que marca o trauma como afeto estrangulado (Favero, 2009).Contudo, uma questão de extrema relevância que precisa ser respondida, é por que a memória do trauma é dissociada? Como veremos no próximo tópico Freud acreditava que o trauma originava uma patologia histérica. Dessa forma, a memória do fato traumático era dissociada porque causava angústia, tendo em vista que entrava em confronto com ideais ou desejos significativos para aquele sujeito (Rudge, 2009).

\subsection{2}

\section{O primeiro tempo do trauma}

A fim de tentar responder sobre o porquê da dissociação psíquica nas pacientes histéricas, Freud inicia a investigar o conflito psíquico, e o trauma sexual começa a ser protagonista na sua investigação, pois eram de ordem sexual os acontecimentos traumáticos que geravam tais conflitos:

as clientes que Freud atentamente ouvia falavam sobretudo de temas sexuais. Isso levará Freud, em 1896, a caracterizar o trauma psíquico que estaria na origem da neurose como um trauma sexual precoce: a sedução da criança por um adulto (Rudge, 2009, p. 18).

Assim, se construía a primeira teoria do trauma que é situada no período de 1895 a 1905, denominada "teoria da sedução". Essa teoria se baseava nas investidas (geralmente de um adulto) por meio de palavras ou gestos ou até mesmo 
do ato sexual, que o outro individuo sofre passivamente e com pavor (Laplanche $\&$ Pontalis, 1982/2016). Os autores ressaltam que a passividade do sujeito na cena não evoca qualquer resposta: "sem que ele faça eco a reapresentações sexuais: o estado de passividade é correlativo de uma não preparação. A sedução produz um 'pavor sexual"” (Laplanche \& Pontalis, 1982/2016, p., 470). Em Estudos sobre a histeria (1985) Freud enfatizou o quanto o trauma vivido pelo sujeito incidia diretamente sobre a constituição da neurose, principalmente quando elaborou sobre o significado etiológico do trauma nas neuroses. Assim segundo Favero:

Freud se apoia numa evidência clínica - a lembrança de traumas das crianças que são vítimas de abusos sexuais é tão penosa que todos preferem esquecêlos, recalcando-os. A partir dessa primeira hipótese da causalidade sexual da neurose e do recalque com base na teoria da sedução de origem traumática, a noção de trauma ocupa um lugar historicamente fundamental na psicanálise (2009, p. 23).

Esse trauma, portanto, ocorreria em dois tempos: o primeiro tempo no momento da sedução, quando a criança é sexualmente investida por um adulto e não registra isso como acontecimento traumático, pois não há ferramentas para integrar o evento. O segundo tempo se manifesta anos depois [a posteriori] em uma cena aparentemente inofensiva em que o indivíduo irá recordar o primeiro cenário por algum traço organizacional. É nesse segundo momento que o trauma é manifestado (Oliveira, 2014). Neste ponto ressaltamos que o sujeito ainda criança é passado como assexuado, ou seja, inapto de ter aptidão sexual que lhe possibilitasse qualquer tipo de excitação dessa natureza (Laplanche \& Pontalis, 1982/2016; Oliveira, 2014). Assim, Uchitel descreve esse fenômeno como:

duas cenas são necessárias para que o trauma ocorra: uma primeira que, para adquirir valor etiológico, deve acontecer cedo (até os 10 anos de idade), produzir uma sensação de irritação nos genitais e ser vivida de forma submissa e passiva pela criança, que nesse momento só sente o impacto, mas nada compreende; e uma segunda cena, em um segundo tempo, do a posteriori (em que, mais do que uma sequência de cenas, observa-se uma sobreposição da cena atual com a da marca mnêmica) que o evento se torna traumático. $O$ trauma não se localiza na vivência da vida adulta, mas no reviver a posteriori a intensidade que evoca a primeira cena. (...) A primeira cena oferece força traumática, enquanto a segunda condição é traumatizante (Utchitel, 2011, p. 34).

Essa teoria foi a primeira formulada por Freud, nos primórdios da psicanálise, para buscar explicar a etiologia das neuroses; contudo em 21 de setembro de 1897 escreveu sua famosa carta a Fliess, onde apontará que não 
acredita na sua neurótica e voltará atrás no seu posicionamento na teoria das neuroses (Rudge, 2009; Oliveira, 2014). Foram duas as principais razões que levaram a Freud a descrever o insucesso da clínica:

A decepção repetida de sua expectativa de levar, pelo menos um tratamento psicanalítico até o que considerava uma verdadeira conclusão. O segundo motivo foi a frequência dos casos de histeria. Partindo do raciocínio de que, caso sua hipótese da sedução sexual fosse verdadeira, haveria um número muito maior de pais perversos do que de histéricos (...) Freud concluiu ser impossível que a quase totalidade dos pais fosse pervertida (Rudge, 2009, p. 23)

Nesse momento, ao abandonar a teoria da sedução, Freud abre novos caminhos para a jovem psicanálise, pois consumou que o trauma ocorria devido a fantasias, que são demonstração de desejos. Assim, a ótica investigada foi modificada uma vez que o indivíduo que buscava a análise estava no papel de vítima, o objetivo do tratamento seria conduzi-lo a exibir-se como sujeito da própria história psíquica e como sujeito edípico desejante (Rudge, 2009; Janin, 2005; Oliveira, 2014). Nesse cenário, Freud percebeu que deveria haver uma sexualidade na infância destinada primeiramente aos pais, que são os primeiros objetos de afeto e desejo do infante (Rudge, 2009).

A renúncia à teoria da sedução abriu caminho para novas descobertas, como a sexualidade infantil e o complexo de Édipo. Assim, segundo Freud: "Houve a percepção de que essas fantasias se destinavam a encobrir, adornar e situar num nível mais elevado a atividade erótica dos primeiros anos da infância, então por trás dessas fantasias, apareceu a vida sexual da criança em toda sua amplitude" (Freud, 1914/2019, p. 260).

Ressalta-se nesse contexto que a teoria da sedução: "uma vez descartada, passará a ser considerada em textos posteriores como origem da sexualidade" (Lejarraga, 1996, p.7) e a ideia do a posteriori ainda permanece central na teoria psicanalítica (Janin, 2005; Oliveira, 2014; André, 2008). Nesse sentido, sublinhamos o quanto foi preciso, para o avanço da psicanálise, abandonar a teoria da sedução; contudo, não o modelo do a posteriori. Assim Freud renunciou à proposta do trauma sexual, mas não ao conceito de que a pulsão sexual é o causador principal da neurose. O Édipo e a sexualidade infantil são indícios desse novo cenário, onde o sujeito atravessa de vitimizado para desejante (Janin, 2005; Douville, 2003; Oliveira 2014). 
Assim, com a renúncia da neurótica freudiana, os acontecimentos traumáticos passaram a ser relacionados com as fantasias de sedução, castração, complexo de Édipo, cena primitiva etc. gerando conflitos psíquicos e consequentemente angústias para o sujeito em questão (Winograd, Klatau, \& Sollero-de-Campos, 2014; Oliveira, 2014). “Agora, o traumatismo era concebido como sendo expressão direta da força das pulsões sexuais em sua luta com o Eu e vice-versa - eis o segundo momento deste primeiro período" (Winograd, Klatau \& Sollero-de-Campos, 2014, p. 159). Diante de todo esse novo cenário podemos acrescentar que o trauma não tinha mais uma posição plena na origem da neurose. Além disso, acrescentamos que: “o traumatismo até 1920, respeita as condições impostas pelo princípio do prazer, que dirige a vida mental através do propósito principal de evitar o desprazer" (Oliveira, 2014, p. 25).

Notamos o quanto esse momento da renúncia à teoria da sedução e a descoberta da sexualidade infantil e do complexo de Édipo são fundamentais para compreendermos os próximos passos de Freud na teoria psicanalítica. Vamos analisar a seguir que apesar de a sexualidade continuar em evidência na clínica, o trauma, devido às questões históricas e políticas da época, se recolocou sob os holofotes como tema fundamental para o estudo dos psicanalistas, ainda que em novo formato (Rudge, 2009). As neuroses de guerra e por sua vez as neuroses traumáticas são essenciais para conceber nossa proposta nesta investigação: estudar as consequências psíquicas sobre a mulher que foi brutalmente desobjetalizada e teve seu corpo utilizado como arma de guerra sem seu consentimento, sendo violentada e cruelmente atacada. Afinal, quais são os frutos traumáticos para quem é barbaramente usada em um conflito armado por uma razão política maior?

\subsection{3}

\section{Neurose traumática e neuroses de guerra}

Antes de elaborar o Além do princípio do prazer em 1920, Freud, já em 1916, tomado pela selvageria da Primeira Guerra Mundial, começou a estudar a questão das neuroses traumáticas do pós-guerra. Portanto, podemos dizer que a ideia do trauma retorna de outra forma entre os anos de 1915 e 1920.

A neurose traumática é um tipo de neurose: "em que o aparecimento dos sintomas é consecutivo a um choque emotivo, geralmente ligado a uma situação em que o sujeito sentiu a sua vida ameaçada" (Laplanche \& Pontalis, 1982/2016 p. 315). 
Essa nova concepção da percepção do trauma foi a princípio proposta por Freud devido aos novos casos de neurose traumática do pós-guerra, que derivavam de experiências tenebrosas que não tinham ligação direta com a sexualidade (Favero, 2009).

Além disso, as neuroses de guerra, sendo originárias dos campos de batalha, geraram entusiasmo nos analistas pela neurose traumática, o que ocasionou frutos importantes para a teoria do trauma e para a psicanálise de uma maneira mais abrangente. Os analistas, por sua vez, buscavam investigar as neuroses de guerra, pois traziam graves consequências psíquicas para os militares, acometendo seu desempenho (Rudge, 2009). Contudo, não podemos afirmar que a neurose de guerra seja uma categoria clínica, que advenha da categoria da neurose traumática estabelecida em 1889 por Hermann Oppenheim (1858-1919), que a relatou como uma "afecção orgânica consecutiva a um trauma real, provocando uma alteração física dos centros nervosos, uma vez que acompanhada por sintomas psíquicos: depressão, hipocondria, angústia, delírio etc." (Roudinesco \& Plon, 1998 p. 537). Nessa mesma época, Freud foi solicitado a ser perito e dar um parecer sobre uma função que exercia Julius Wagner-Jauregg, psiquiatra acusado de empregar choques elétricos em soldados tomados pela neurose de guerra, que em sua realidade eram considerados como simuladores. Em seu relatório, Freud criticou a eletricidade como forma de tratamento e a ética dos que o aplicavam aos doentes. Além disso, repeliu a ideia de que os sintomas mostrados pelos soldados fossem resultado de simulação (Favero, 2009; Rudge; 2009).

O conflito mundial exigiu de Freud uma nova forma de abordar a etiologia das neuroses, diferente daquela a que tinha se dedicado na sua clínica até então. Assim, as neuroses, para se diferenciar das traumáticas, foram chamadas de espontâneas (histeria, neurose obsessiva, fobia) (Favero, 2009). As neuroses traumáticas eram misteriosas e não se enquadravam com facilidade na teoria das neuroses já formada para estudar as histerias, fobias e neuroses obsessivas (Rudge, 2009). A principal diferença entre elas - neurose espontânea e neurose traumática - é que a neurose traumática claramente mostrava sinais de fixação no momento do acidente traumático. Segundo Freud (1917/2014): "Nos sonhos, os que dela sofrem revivem regularmente a situação traumática (...). É como se esses doentes jamais tivessem superado a situação traumática" (p.367). No decorrer de sua investigação teórica e clínica, Freud começou a perceber que essa fixação no acontecimento 
traumático era o principal fator que acometia o fracasso do sonho em somente satisfazer a ordem do desejo(Rudge, 2016). Assim, esse período foi fundamental para a formulação de futuras teorias como o Além do princípio do prazer, afinal era preciso responder porque os sinais de fixação eram presentes no sujeito e porque apenas o caminho da realização do prazer não era mais o único.

As neuroses traumáticas de pós-guerra eram destacadas pela particularidade de se fixarem no momento do acidente traumático, e assim Freud começou a reformular os sonhos e a reaparecer na forma de ataques que se presume conduzirem repetidamente o sujeito para o cenário do trauma (Favero, 2009; Rudge, 2009). Desse modo, segundo Rudge (2009):

Os sintomas mostram que é impossível superar o trauma. O mais característico e intrigante é o reviver repetido e quase alucinatório do acontecimento traumático, sintoma hoje chamado de flashback e que não é verdadeiramente alucinatório porque o sujeito sabe que o fato traumatizante não está ocorrendo novamente. O sentimento depressivo, o desânimo e a tristeza estão sempre presentes (p. 40).

Tomado pela temática da brutalidade, violência e selvageria da Primeira Guerra Mundial, Freud, em 1918 apresentou um trabalho no V Congresso Internacional de Psicanálise em Budapeste, em que confirmou a ausência da etiologia sexual nas neuroses de guerra, uma vez que estas são promovidas por um agente externo, enquanto nas neuroses de transferência a ameaça se origina das próprias pulsões (Rudge, 2009). De acordo com Freud (1917/2014):

Nas neuroses traumáticas e de guerra, o Eu do indivíduo se defende de um perigo que o ameaça desde fora, ou que é corporificado numa postura do próprio $\mathrm{Eu}$; nas neuroses de transferência, o Eu toma sua própria libido como inimigo, cujas reivindicações lhe parecem ameaçadoras. Em ambos os casos o Eu teme ser ferido: neste último, pela libido; naquele, pelos poderes externos (p. 387-388).

É necessário ressaltar que apesar de toda dedicação de Freud na distinção das neuroses e na preocupação de diferenciar as neuroses traumáticas das espontâneas, alguns psicanalistas, a partir da Segunda Guerra Mundial, com o retorno do tema da neurose traumática, negavam ainda sua existência, uma vez que defendiam que não havia uma neurose específica formulada para situações de guerra, isto é, a neurose traumática. Dessa forma, a maioria considerava que as neuroses traumáticas eram neuroses como todas as outras, com a única diferença de terem um fator estimulador muito severo (Rudge,2009). 
Contudo, não podemos concordar que não haja distinção entre o trauma ocorrido em tempos de paz e aquele em tempos de guerra. $\mathrm{O}$ trauma ocorrido em tempos de paz, por mais violento que seja, não caracteriza a mesma proporção de estar submerso a situações sub-humanas, como as que estamos estudando nesta pesquisa, onde a mulher tem seu corpo usado como ferramenta de guerra pelo inimigo e tendo sua subjetividade anulada. Entretanto, devemos destacar que há sujeitos que passam verdadeiras cenas de horror nas cidades. Souza (2005) relembra que no ano de 2004 dez moradores de rua foram atacados de forma desumana na Cidade de São Paulo. Os ataques continuaram com outros moradores desse mesmo local e de outras cidades; os efeitos desses ataques levaram a mortes e lesões graves nos habitantes. Assim, a autora acrescenta que Contardo Calligaris, se questionou sobre "Quem tem medo dos moradores de rua" em sua coluna na Folha de S. Paulo (2004) recordou cenas de horror que ocorreram em outros momentos em diversas áreas do Brasil, como o massacre da Candelária, o assassinato do índio Galdino em Brasília e o homicídio de travestis e homossexuais. Souza (2005) sobre esses eventos acrescenta que: "as cenas retomadas (...) são de extrema crueldade e em todas elas, os sujeitos violentados e assassinados são tratados como coisas, dejetos a serem retirados do mundo para que se mantenha a "eugenia" da cidade" (p.37).Portanto, para nós é claro que para muitos a vida, mesmo em tempos de “paz”, é uma verdadeira guerra.

Segundo Diken e Laustsen (2005), em sua pesquisa teórica sobre a guerra da Bósnia e os efeitos traumáticos que o estupro como arma de guerra pode causar,observaram que os danos são muito maiores do que somente os prejuízos corporais. As mulheres muitas vezes se sentem "sujas" e moralmente inferiores. Além disso, também podem ser excluídas pelos vizinhos e membros da família. Os autores ressaltam que a penetração ocorrida no ato do estupro inflige no corpo da mulher uma marca e um estigma que não podem ser ignorados. Além disso, o aspecto social é evidente, pois além de ser estuprada também é condenada pela sociedade patriarcal. Não podemos deixar de sublinhar que a constituição prévia do sujeito influencia o efeito traumático, já que o trauma não pode ser definido somente pelo fato em si. Até mesmo a guerra não é uma experiência traumática igual para todos os combatentes, uma vez que cada um tem uma singularidade e organização psíquica próprias (Rudge, 2009). Retomaremos esta discussão adiante. 


\subsection{4}

\section{O segundo tempo do trauma}

Até o momento como analisamos, Freud trabalhava somente com a hipótese de que o psiquismo em qualquer circunstância buscava encontrar o prazer e evitar o desprazer. Essa seria a proposta fundamental de funcionamento do aparelho psíquico, que Freud nomeou de princípio do prazer (Rudge,2009). As terminologias prazer e desprazer foram elaboradas por Freud e regem um sentido preciso onde, a partir do sistema da economia psíquica, o desprazer é entendido como um aumento da quantidade de excitação, ao mesmo tempo em que o prazer é demonstrado como um rebaixamento de tensão (Scarfone, 2005).

Como relatamos anteriormente, a neurose traumática, com os sonhos traumáticos peculiares e a fixação no acontecimento traumático, foi o primeiro problema clínico do princípio do prazer. Nesse cenário, a questão que Freud levanta em 1920 é como aliar as experiências desprazerosas que agem de maneira constante reatualizando o acontecimento traumático com o até então princípio do prazer, regedor do psiquismo (Rudge, 2009; Uchitel, 2011; Freud, 1920/2010). Rudge afirma que:

a repetição incessante da experiência traumática e dolorosa nesse tipo de neurose, seja por rememorações vívidas, alucinações ou sonhos, terminará por convencer o mestre de Viena que não é sempre que o psiquismo busca obter o prazer e evitar o desprazer. Freud admitirá que há uma compulsão à repetição que também tem importante papel no psiquismo e que é anterior ao princípio do prazer (Rudge, 2009, p.48).

Nesse cenário, é importante destacarmos que nessa nova versão, repaginada em 1920, a ênfase está não no que desencadearia o trauma (como na teoria da sedução, marca do primeiro contato de Freud com a problemática do trauma psíquico, e nas revisões feitas posteriormente) mas é entendido como um excesso de energia livre, sem que o Eu tenha, pelo susto, pela intensidade da(s) experiência(s) ou por sua constituição específica, a capacidade de ligar e elaborar no aparelho psíquico essas excitações - cujo caráter excessivo se revela na experiência do sujeito, ou seja, nos momentos em que seus recursos psíquicos são chamados a mostrar sua (im)potência. Não por acaso, essa nova dimensão do traumático de 1920, nomeado de aspecto econômico, aflora dois anos após a Primeira Guerra Mundial. 
Na guerra se viu, como nunca e da pior maneira, como o trauma, de acordo com a perspectiva econômica, precisa ser visto como afluxo de quantidade demasiada, causada por agentes internos e/ou externos, superando a capacidade do psiquismo de elaboração e ligação. O traumático, então, estaria além da possibilidade de alguma forma de representação psíquica para o sujeito (Maldonado \& Cardoso, 2009). De acordo com Laplanche e Pontalis (1982/2016, p. 522), "trauma" pode ser caracterizado como:

Acontecimento da vida do sujeito que se define pela sua intensidade, pela incapacidade em que se encontra o sujeito de reagir a ele de forma adequada, pelo transtorno e pelos efeitos patogênicos duradouros que provoca na organização psíquica. Em termos econômicos, o traumatismo caracteriza-se por um afluxo de excitações que é excessivo em relação à tolerância do sujeito e à sua capacidade de dominar e de elaborar psiquicamente estas excitações.

Nesse novo modelo, iniciado em 1920, o trauma é identificado com um excesso, ou seja, um acúmulo de excitação difícil de ser suportado pelo aparelho psíquico. Freud (1920/2010) apresenta “a neurose traumática ordinária como a consequência de uma vasta ruptura da proteção contra os estímulos" (p.194).

Assim, Freud acreditava que havia abundância de excitação que seria apta a romper o escudo protetor ou paraexcitação do psiquismo. Com o aumento de excesso, o nível da tensão psíquica também aumenta, transcendendo a capacidade de elaboração do aparelho psíquico, que fica impedido de dar um rumo a qualquer quantidade que tente penetrar (Oliveira, 2014). Como indica Uchitel (2011):"O trauma seria a consequência do excesso de excitação" (p.66).

Nesse cenário, analisando a formulação hipotética da vesícula elaborada por Freud, o autor construiu um modelo onde será possível teorizar sobre o trauma. Essa vesícula é voltada para o mundo exterior e seria exterminada se não fosse sua “proteção contra estímulos". A camada mais exterior se torna inorgânica para deter os estímulos, e as camadas mais profundas permanecem vivas, assim podemos dizer que a morte preservou a vida. Contudo, quando ocorre o aumento da excitação, pode haver o perfuramento da barreira de proteção, gerando experiências traumáticas, ou seja, essa abundância de energia gera um ataque à vesícula que não estava preparada (Freud, 1920/2010; Uchitel, 2011; Cardoso, 2011). Maia (2005) nos ajuda a pensar essa problemática, ao evidenciar que o fato será traumático ou não pela relação de forças que se definem entre aquilo que invade o psiquismo de 
maneira repentina e o quantum de reserva de energia com que será capaz contar para lidar com um elemento que o desestabiliza. Assim, nas palavras de Freud (1920/2010):

As excitações externas que são fortes o suficiente para romper a proteção nós denominamos traumáticas. (...) Um evento como o trauma externo vai gerar uma enorme perturbação no gerenciamento de energia do organismo e pôr em movimento todos os meios de defesa. Mas o princípio do prazer é inicialmente posto de fora de ação. Já que não se pode evitar que o aparelho psíquico seja inundado por grandes quantidades de estímulo; surge, isto sim, outra tarefa, a de controlar o estímulo, de ligar psicologicamente as quantidades de estímulo que irromperam, para conduzi-las à eliminação (p.192).

Contudo, é necessário destacar que não só estimulações do exterior a vesícula viva recebe, como nos mostra Freud; durante a experiência traumática há excitação também vinda do interior do psiquismo o que torna impossível a proteção contra esses estímulos, pois percorrem de forma direta o sistema (Borges, 2012; Freud, 1920/2010). Como nos indica Borges (2012): "não há escudo protetor eficaz" (p.29).

Nesse instante o princípio do prazer é deixado de lado pelo psiquismo que se concentrará em ligar o excesso de energia livre que excede no aparelho psíquico. Contudo, devemos estar atentos às diferenças essenciais da noção de ligação de acordo com o contexto teórico, pois foi utilizada em diversos momentos na obra freudiana como: "Projeto para uma psicologia científica" (1985) ou em "A interpretação dos sonhos" (1900). Afinal fica o questionamento: ligar o quê? (Maia, 2005; Laplanche \& Pontalis,1982/2016).

Como indicam Laplanche e Pontalis (1982/2016) é possível descrever três distintas formas para a noção de ligação. A primeira se estrutura no ano de 1895 na obra Projeto para uma psicologia científica, que foi o primeiro momento em que apontou a ideia de o aparelho neurônico passar do estado livre ao ligado. Os conceitos de ligação energética e energia livre são analisados em uma percepção econômica onde a primeira demonstra relação de viabilizações entre um campo já investido e o acréscimo de novos neurônios. A segunda por sua vez, são casos em que há tendência irrefreável de descarga de energia (Laplanche \& Pontalis, 1982/2016; Maia; 2005).

A segunda estrutura surge em Além do princípio do prazer com uma composição mais complexa, pois nesse momento não é mais possível sustentar 
somente com o princípio do prazer, pois com a repetição do traumatismo e a repetição das experiências desagradáveis foi necessário recorrer a uma nova ordem de ligações. Por fim, na terceira estrutura a ligação pode ser encontrada pela oposição da pulsão de vida com a pulsão de morte; assim é possível ser analisada na perspectiva da última teoria pulsional (Laplanche \&Pontalis, 1982/2016; Maia, 2005).

Retomando as experiências traumáticas, como analisamos no tópico anterior no ano de 1916, tomado pela brutalidade da Primeira Guerra Mundial, Freud antes de elaborar o Além do princípio do prazer já percebia que havia na neurose traumática sinais de fixação no momento traumático. Como complementam Winograd, Klautau e Sollero-de-Campos (2014), quando Freud elabora o Além do princípio do prazer fica evidente que uma das principais marcas do trauma é uma forma de congelamento ou fixação, o que impede suas articulações em sua rede representacional. Segundo as autoras a fixação no traumático seria um fluxo regressivo desorganizador como efeito da desvinculação pulsional - que pode ser causada por um acontecimento atual ou pela história da constituição psíquica - e consequentemente a intensificação da pulsão de morte (Winograd, Klautau \& Sollero-de-Campos, 2014). Uchitel (2011) complementa essa teoria ao dizer que: "o conceito de fixação enriquece a compreensão do trauma" (p.67). Dessa forma, somos capazes de dizer que os sonhos não se constituem somente em realização alucinatória de desejos, como antes acreditava Freud, e sim há sonhos traumáticos repetitivos, que respeitam a compulsão e a repetição (Winograd, Klautau \& Sollerode-Campos, 2014; Freud 1920/2010). A compulsão à repetição, por sua vez não se relaciona com a lógica do princípio do prazer, nem com a realização do desejo, e atua de forma a dominar o excesso de excitação causado pelo trauma. Assim, podemos dizer que esse sistema da compulsão à repetição atuante no trauma e na neurose traumática, respeita o fluxo da pulsão de morte: da redução total das tensões, do retorno ao estado inorgânico, da não ligação, do desprazer, do não sexual (Uchitel, 2011). Segundo Freud (1920/2010): “(...) a compulsão à repetição também traz de volta experiências do passado que não possibilitam prazer, que também naquele tempo não podem ter sido satisfações (...)” (p.179).

Ressaltamos o quanto essas experiências traumáticas que são da ordem do além do princípio do prazer, possuem excesso de energia elevada a ponto de romper o "escudo protetor" e promover impactos no psiquismo. Assim, para Knobloch, 
(1998) o trauma se dá pela incapacidade de representação, da não elaboração e da não organização, podendo ser caracterizado de não representável. Nesse seguimento, Maia (2005) complementa: "a vivência traumática ocorre por um excesso emocional inassimilável e irredutível ao campo das significações vigentes; o episódio traumático se dá no limite das possibilidades de narrativa” (p.94).

Como analisamos neste capítulo, o trauma na teoria psicanalítica descrita por Freud sofreu diversas modificações ao longo de sua obra. Acreditamos que o estupro como arma de guerra seja um evento potencialmente traumático e se encaixaria no segundo momento do trauma, pelo tamanho do seu horror, por seu excesso de excitação do aparelho psíquico e insuficiência de elaboração.

\section{2}

\section{Efeitos traumáticos da dessubjetivação pelo estupro na Guerra}

Quando nos referimos à violência praticada em qualquer sistema de poder, devemos prestar atenção ao fato de que nenhuma ideologia efetua a violência pela violência. Há em sua maioria um objetivo maior que pode ser em nome da revolução, da independência ou da libertação (Dadoun, 1998). No caso da guerra da Bósnia, o corpo da mulher entra em uma nova perspectiva, onde antes a violência sexual era vista como consequência dos conflitos armados, agora o corpo da mulher se transforma em uma arma de guerra capaz de exterminar um Estado através da limpeza étnica e, consequentemente, do genocídio. Observando o cenário da época, de grande instabilidade política e econômica da ex-Iugoslávia, podemos dizer que a violência cometida na Bósnia tem como fim realizar uma grande limpeza étnica, o principal objetivo dessa homogeneização populacional.

A mulher nesse conflito é violentada de duas principais formas: seu corpo é invadido e agredido sem seu consentimento e se transforma em uma munição de guerra para uso do território inimigo, invalidando sua subjetividade e sendo totalmente desinvestida. É possível dizer que nessa situação - em que perde sua subjetividade, sua capacidade de decisão sobre o próprio corpo - a mulher é intensamente anulada e esvaziada como sujeito, e a situação é potencialmente traumática e causa um excesso de excitação. Isto é, uma abundância de energia livre difícil de ser suportada pelo psiquismo, sem a possibilidade de ligação e 
representação. Assim, segundo Lima e Werlang (2011) o trauma se refere a uma dor irrepresentável psiquicamente que traz forte impacto no processo de subjetivação do sujeito.

É relevante sublinhar que o cenário cultural de determinado período pode ter consequências para a organização da subjetividade de cada indivíduo. Assim, a particularidade de cada época gera efeitos importantes na subjetividade de cada sujeito, a ponto de julgarmos que a subjetividade é própria de cada período temporal (Júnior \& Besset, 2010). Nesse seguimento, nos questionamos como se estruturou a subjetividade das mulheres que viveram em um momento de conflito bélico e tiveram seus corpos brutalmente desinvestidos, invadidos, usados sem sua permissão, e foram transformadas em meros objetos com o fim de destruição e exterminação de sua própria nação. Acreditamos que a mulher sofre nesse processo extrema desobjetalização, ou seja, é anulada e intensamente dessubjetivada, visto que o estupro e, por sua vez, o trauma proveniente desse acontecimento, é uma arma dessubjetivante com acentuado poder de esvaziamento do sujeito. Em contrapartida, seu corpo é investido uma vez que se converte meramente em um campo de batalha em prol de um objetivo maior e coletivo, que é a guerra.

Ressaltamos que a guerra é um fenômeno que não afeta somente um sujeito e sim todo um sistema que está envolvido. Neste estudo estamos nos relacionando principalmente com o sintoma subjetivo da mulher que é violentada no conflito bélico; porém, queremos destacar que há também o sintoma social. Contudo, sublinhamos que não há a intenção de nos limitarmos no significado do sintoma, mas sim de prestarmos atenção às diferenças das classificações de sintomas segundo Junior e Besset (2010), para assim contextualizarmos o estupro como arma de guerra nessas categorizações. De acordo com os autores, o sintoma social é algo que interfere na expressão de homogeneidade da ordem social definida. Essa categoria coletiva permite a manifestação de características em comum. Quando nos referimos ao estupro como arma de guerra, por exemplo, podemos considerar uma questão social por ultrapassar um limite de ordem social previamente determinada. Apesar de não estarmos nos referindo a um contexto que invade os tempos de paz, o estupro como arma de guerra domina uma conjuntura importante e complexa que combina a violência contra a mulher, sua histórica submissão ao homem e o momento crítico econômico e social em que se encontrava a exIugoslávia. Nesse sentido, é possível julgar que o estupro como arma de guerra é 
um sintoma social que excedeu o arranjo estabelecido preliminarmente, antes do conflito bélico.

Além disso, é do nosso lugar como analistas escutar o subjetivo de cada sujeito; portanto, para Junior e Besset (2010) o sintoma subjetivo é aquele em que é possível compreender a singularidade de cada um. No caso no estupro como arma de guerra acreditamos que, por se tratar de um quadro de violência ocorrida em tempos de guerra, se diferencia da violência em tempos de paz. Pois, apesar de ambas apresentarem potenciais traumáticos para o indivíduo, a violência de que estamos tratando em tempos de guerra, é devastadora não só para as próprias mulheres, mas também para os filhos que são fruto do estupro e para suas famílias, que muitas vezes são obrigadas a assistir a esse massacre além de frequentemente serem obrigadas pelo grupo inimigo a se estuprarem uns aos outros.

Desse modo, Maia (2005) argumenta que a experiência traumática coloca em evidência qualquer alternativa de narrativa sobre o ocorrido, enfrentando a memória e qualquer chance de elaboração psíquica. $\mathrm{O}$ acontecimento traumático é dessubjetivante quando apresenta violação, um cenário de dor sem a possibilidade de mediação. Segundo a autora: "O maior problema que se coloca frente à tentativa da narrativa do horror diz respeito à sua irrepresentabilidade: a experiência do horror é incomensurável e nenhuma palavra ou conceito poderá fazer jus a sua tradução" (p.145). O estupro como arma de guerra é uma violência tão invasiva que impossibilita à mulher sua capacidade de escolha quanto ao seu próprio corpo, sendo usada como instrumento em uma batalha bélica, com propósitos de exterminação e destruição. Esse cenário é de horror, e não permite ser representável. 


\section{Considerações finais}

Como vimos ao longo de nosso estudo, a desigualdade de gênero, a sociedade patriarcal e a submissão feminina estiveram e estão presentes historicamente em nossa sociedade, sendo o estupro uma violência que acontece ao longo dos tempos.

Nas guerras, durante muitos anos, o estupro era visto como consequência dos conflitos armados; entretanto esse cenário mudou no conflito da ex-Iugoslávia, principalmente na Bósnia, já que passou a ser utilizado com um objetivo específico de guerra que era a limpeza étnica. O estupro, dessa maneira, não deve ser entendido somente como um dano colateral aparentemente mais cruel de uma guerra, pois é em muitos casos usado como verdadeira arma tão ou mais potente que qualquer AR15, e com potencial de destruição similar a bombas atômicas. Foi com essa perspectiva, dos casos de estupro como arma de guerra, que nosso estudo se propôs a investigar.

Percebemos que analisar o cenário político e social em que se encontrava a ex-Iugoslávia foi fundamental para compreender como o estupro foi realizado nos conflitos armados como arma de guerra. Nesse sentido, concebemos que a Iugoslávia até o início dos anos noventa era composta por seis repúblicas: Sérvia, Macedônia, Croácia, Eslovênia, Montenegro e Bósnia-Herzegovina. As federações foram crescendo de forma desigual, visto que enquanto Sérvia, Eslovênia e Croácia se destacavam economicamente, as outras regiões não alcançavam tal desempenho. Consequentemente, houve a quebra das federações, o que ocasionou diversas crises e brutais conflitos étnicos (Albanese, 2001). Esses conflitos étnicos foram responsáveis por tentativas de realizar a limpeza étnica e logo a homogeneização da população. Em nosso estudo, focamos no contexto em que a Sérvia buscava transformar a Bósnia em uma grande Sérvia. Portanto, para que isso ocorresse, as mulheres eram levadas para campos de estupro, bordéis ou até mesmo em suas próprias casas e eram estupradas compulsoriamente. Muitas vezes eram mantidas em cativeiro até que sua gestação ficasse avançada demais para abortar (Mullins, 2009). Notamos que, pela conjuntura em que ocorreu o estupro na Bósnia, podemos considerar como genocídio. Uma vez que, foi uma violação tanto ao sujeito quanto ao grupo a que pertencia. Dessa forma, o estupro pode ser entendido como um 
instrumento eficaz que pode acometer gravemente o corpo ou a saúde mental do sujeito e/ou do grupo (Vitto, Gill \& Short, 2009).

Examinamos o quanto a violência é fator marcante e presente nos conflitos armados, além de ter sido de fundamental importância para os negócios humanos, podendo também ser caracterizada como intensa manifestação de poder (Arendt, 2016). No campo psicanalítico, a violência apresenta falta de metodização e, no discurso freudiano, por muitas vezes foram utilizados termos com diferenças como: violência, crueldade, maldade, hostilidade, vingança, ódio, agressão e destruição (Pereira, 2006). Assim, o vocábulo violência se demonstrou em muitos cenários como confuso, impreciso e despropositado (Costa, 2003). A guerra, por sua vez, se mostrou um fator notável que atravessou a história humana e não há dúvida de sua dura influência na modernidade (Birman, 2009). Ecoando nas palavras de Freud (1932/2010): "um olhar sobre a história da humanidade nos mostra uma série infindável de conflitos entre uma comunidade e outra ou várias outras, entre povos, reinos que quase sempre são resolvidos mediante a prova de força de guerra". Dessa maneira, Freud, atravessado pela barbaridade da Primeira Guerra Mundial foi motivado a estudar sobre esse cruel fenômeno.

Para explorar o evento da guerra na perspectiva psicanalítica analisamos os escritos: "Reflexões sobre o tempo de guerra e morte" (1915) e "Por que a guerra?" (1932), este segundo escrito foi o resultado de cartas trocadas com o físico Albert Einstein. Ambos os textos apresentam as ideias freudianas essenciais sobre a guerra. Nesse contexto, é claro para Freud o quanto a guerra era um desejo de morte da própria classe humana (Roudinesco, 2016). Desse modo, percebemos em nosso estudo que não é possível relacionar a guerra sem citar a pulsão de morte, a pulsão de agressão e a pulsão de destruição. Esses elementos são fundamentais para compreendermos o processo da guerra sob o olhar psicanalítico. Com isso, podemos dizer que o trabalho realizado por Freud em 1920 "Além do princípio do prazer" permitiu a profundidade de sua análise iniciada no ano de 1915 e lapidada em 1932 nas cartas trocadas com Albert Einstein, pois nas cartas Freud se utiliza de ferramentas para explicar algumas tendências antes sem explicação: por que os homens se moviam para a guerra? Por que cometiam crueldades? Essas respostas ainda não estavam disponíveis em 1915; contudo, com a segunda teoria pulsional, elaborada em "Além do princípio do prazer" (1920), Freud conseguiu desenvolver uma nova direção. 
Como observamos até então, na segunda teoria pulsional, a pulsão de morte tinha uma função de desligamento, enquanto a pulsão de vida uma função de ligação. Contudo, Green (1988) propõe dois conceitos: objetalização e desobjetalização, que foram fundamentais para pensarmos o corpo da mulher que é invadido, anulado e usado como arma de guerra. Considerando que na função da objetalização podem coexistir a ligação e o desligamento e a função desobjetalizante pode atacar as ligações do objeto e desfazer as relações presentes, nós percebemos o quanto a mulher é objetalizada quando é investida para ser munição de guerra para um propósito maior que foge de seu controle. Em contrapartida também é desobjetalizada no instante em que é desinvestida, anulada como sujeito e incapaz de consentir sobre o destino do seu próprio corpo.

Nosso trabalho questionou quais eram os efeitos traumáticos para essas mulheres que eram brutalmente violentadas, concomitantemente objetalizadas e desobjetalizadas em um contexto em que seus corpos eram usados como armas de guerra para a tentativa de limpeza étnica e, consequentemente, homogeneização de um Estado. A fim de responder a essa questão analisamos o percurso traumático freudiano e percebemos que o aspecto econômico do trauma, ou seja, o segundo tempo marcado pelo "Além do princípio do prazer" em 1920, se encaixaria no modelo que estamos nos propondo a estudar do estupro como arma de guerra. Acreditamos que o fato de a mulher ser usada como objeto de guerra para um propósito maior, ser anulada como sujeito e esvaziada de sua subjetividade, é um acontecimento potencialmente traumático. Dessa forma, pela falta de capacidade de ligação, há alto nível de excitação no aparelho psíquico, a ponto de perfurar o "escudo protetor", devido ao susto e/ou pela intensidade da experiência, causando grandes impactos ao psiquismo. Maia (2005) enfatiza esse cenário, ao posicionar que: "o trauma se configura por uma ruptura de barreira de proteção da vesícula viva, devido ao excesso de excitações que com ela se chocam” (p. 101).

Por fim, não poderíamos deixar de nos questionar como se estruturaria a subjetividade das mulheres que passaram por um evento potencialmente traumático, no qual seus corpos foram usados sem seu consentimento, anuladas como sujeito, esvaziadas de voz e desejos. Elas foram, portanto, cruelmente dessubjetificadas, deixando de ter qualquer possibilidade de narrativa, elaboração e representação psíquica. Ressoando nas palavras de Maia (2005): 
Em seus aspectos dessubjetivantes, a afetação traumática coloca em xeque qualquer possibilidade de narrativa acerca do ocorrido, desafiando a memória e as possibilidades de elaboração psíquica. $\mathrm{O}$ vivido traumático dessubjetivante se apresenta pela violação: campo de dor sem a capacidade de representação (Maia, 2005, p. 94-95).

O que se destacou nesse percurso é que apesar de termos investigado somente o campo teórico percebemos que estamos tratando do cenário do horror, no qual não há representação e há efeitos traumáticos dessubjetivantes para a mulher que é usada como arma de guerra, violentada em campos de estupro, bordeis ou até mesmo em suas próprias casas e obrigadas a manter a gravidez contra sua vontade. Elas são, portanto, anuladas na condição de sujeitos e esvaziadas de sua subjetividade.

Não podemos deixar de ressaltar que o conflito da ex-Iugoslávia e a guerra da Bósnia são acontecimento histórico de tamanha importância e é muito escasso no campo psicanalítico, dado que o estudo desse tópico é mais aprofundado nos saberes do direito e das relações internacionais, e assim acentuamos a dificuldade de elaboração deste trabalho. Contudo, uma vez que investigamos por um prisma diferenciado, relacionando o conflito dessa guerra e suas consequências com os nossos saberes, contribuímos para um melhor entendimento sobre o que é o estupro como arma de guerra e quais seus efeitos para o sujeito.

Este trabalho pode ser enriquecido por futuras produções para se expandir de novos conceitos e autores. Além disso, se tratando de um tema de tamanha relevância e escassez, acreditamos que há a possibilidade de novas pesquisas não só no campo teórico, pois se trata de um tópico que atravessa o irrepresentável do discurso geracional, ou seja, não só as mulheres são atingidas pelas consequências do estupro na guerra, suas famílias e seus filhos frutos do estupro também são. Assim, não só o presente é tocado pelo horror, como também o futuro e o passado. 


\section{BIBLIOGRAFIA}

AGUILAR, S. L; MATHIAS, A. L. Identidades E Diferenças: O Caso Da Guerra Civil Na Antiga Iugoslávia. Revista Brasileira de História \& Ciências Sociais, 2012. Disponível em: https://repositorio.unesp.br/handle/11449/115243 Acesso em: fevereiro de 2020.

AGUILAR, Sérgio Luiz Cruz. A Guerra Da Iugoslávia: Uma Década De Crise Nos Bálcãs. São Paulo: Usina do Livro, 2003.

ALBANESE, P. Nationalism, War, and Archaization of Gender Relations in the Balkans. Violence Against Women, 999-1023, 2001.

ALVES, José Augusto Landgren. Os Novos Bálcãs. Brasília: FUNAG, 2013

ANDRÉ, J. O acontecimento e a temporalidade: O Après-Coup No Tratamento. Revista de Psicanálise e Cultura, São Paulo, 2008.

ARANTES, M. A. Tortura: testemunho de um crime demasiadamente humano. 2011. Tese de doutorado, Programa de Pós-graduação em Ciências Sociais, Pontifícia Universidade Católica de São Paulo, 2011.

ARAUJO, B. A. Violência Sexual em Conflitos Armados: História e Desafios. Alabastro: Revista eletrônica dos alunos da Escola de Sociologia e Política de São Paulo, 2016. Disponível em:

http://revistaalabastro.fespsp.org.br/index.php/alabastro/article/view/119 Acesso em: fevereiro de 2020

ARENDT, H. Eichmann em Jerusalém - um relato sobre a banalidade do mal (1963). São Paulo: Companhia das Letras, 2000.

.Sobre a Violência. Rio de Janeiro: Civilização Brasileira, 2016.

Askin, K. D. (1997). War Crimes Against Women:Prosecution in International War Crimes Tribunals. The American Journal of International law, 1997.

ASSEMBLEIA GERAL DAS NAÇÕES UNIDAS. Declaração Sobre A Eliminação Da Violência Contra As Mulheres.1993.

AZEVEDO, M. K; MELLO, G. A.O Desenvolvimento Do Conceito De Pulsão De Morte Na Obra De Freud. Revista Subjetividades, 67-75,2015.

BASSANETTI, K. o papel da mulher nos conflitos internacionais: um estudo de caso sobre a guerra da bósnia. Revista Cippus - Unilasalle canoas/rs, 46-67, 2014.

BAYLIS, John; SMITH, Steve; OWENS, Patricia. The Globalization Of World Politics: An Introduction To International Relations. 4th ed. Oxford [Inglaterra]: Oxford University Press, 2008.

BELANÇON, L. P; MUNHOZ, S. J. A crise política e a desintegração da república federativa socialista da iugoslávia. In:VII Congresso Internacional de Hisdtória, 2015.

BÍBLIA SAGRADA. Português. Barueri: Sociedade Bíblica do Brasil, 1993.

BIEHLER, A.WAR CRIMES AGAINSTWOMEN. Criminal Law Forum, 507513,2002 . 
BIRMAN, J. Arquivo da agressividade em psicanálise. Natureza Humana, 357379,2006.

BIRMAN, J. Cadernos sobre o mal. Rio de Janeiro: Civilização Brasileira, 2009.

BLEICHMAR, S. Conceptualización de catástrofe social. Límites y encrucijadas. Clínica Psicoanalítica Ante Las Catástrofes Sociales: La Experiencia Argentina. Buenos Aires: Paidós, p. 35-51, 2005.

BOKANOWSKI, T. Traumatisme, Traumatique, Trauma. Revue française de psychanalyse, $745-757,2002$.

. Variations Sur Le Concept De Traumatisme : Traumatisme, Traumatique, Trauma. Revue Française De Psychanalyse, 891-905, 2005.

BORGES, G. Neurose traumática: fundamentos e destinos. Curitiba: Jaruá, 2012.

BROWNMILLER, S. Against our will: Men, Women and Rape. New York: Fawcett Books, 1975.

BROWNMILLER, S. Making female bodies the battlefield. Newsweek,1993.

CALHOUN, C. Nationalism and ethnicity. Annu. Rev. Sociol., 211-239,1993.

CARDOSO, M. Das Neuroses Atuais Às Neuroses Traumáticas: Continuidade E

Ruptura. Revista Lationoamericana de Psicopatologia Fundamental, 14, 70-82, 2011. Disponível em:

http://www.scielo.br/scielo.php?script=sci_arttext\&pid=S1415-

47142011000100005. Acessado em fevereiro de 2021. Acesso em: fevereiro 2020

CLAUSEWITZ, K. V. Da guerra. São Paulo: Martins Fontes,1979.

COPLEON, R. Surfacing Gender: Re-Engraving Crimes Against Women in Humanitarian Law. Hastings Women's law Journal, 243-266, 1994.

COSTA, J. F. Violência e Psicanálise. Rio de Janeiro: Graal,2003.

DADOUN. A Violência: ensaio acerca do "homo violens". Rio de Janeiro:

Difel,1998.

DICIONÁRIO MICHAELIS, 2019. Disponível em: https://michaelis.uol.com.br/ Acessado em: junho 2020

DIKEN, B. ; LAUSTSEN, C. B. Becoming Abject: Rape As A Weapon Of War. Body \& Society, 111-128, 2005.

DOUVILlE, O Du Choc au Trauma... Il y a plus d'un temps. Figures de la psychanalyse, N.8, 2003.

ECO, U. Fascismo Eterno. Rio de Janeiro. Editora Record, 2020.

EINSTEIN, A. ; FREUD, S. Um Diálogo Entre Einstein E Freud. Por Que A Guerra? . São Paulo: Fadisma, 2005.

ELLENBERGER, H.F. The Discovery of the Unconscious: The History And Evolution Of Dynamic Psychiatry. New York: Basic Books, 1970.

ENRIQUEZ, E. Da horda ao estado: Psicanálise do Vínculo Social. Rio de Janeiro: Jorge Zahar Editor, 1990. 
FALCÃO, L. Cem anos de narcisismo: aquém da psicanálise e além de Freud.

Revista Brasileira de Psicanálise, 41-56, 2014.

FARIA, C. G. Sobre a possibilidade ou a impossibilidade para ser e usufruir: entre existir e des-existir. In: $2^{\circ}$ Congresso Latino-Americano de

Psicanálise - FEPAL, São Paulo, 2012.

FARIAS, H. C. (2018). Guerras Hegemônicas e Ordem Internacional. Sobre a Guerra. Petrópolis: Editora Vozes, 2018.

FINAL REPORT OF THE COMMISSION OF EXPERTS ESTABLISHED PURSUANTT O SECURITY COUNCIL Resolution 780 (1992), U.N. SCOR. Doc. S/1994/674 (1994) Ihereinafter Final Report.

FIORI, J. L. Dialética Da Guerra e Da Paz. Sobre a Guerra Petrópolis: Editora Vozes, 2018.

FAVERO, A. A Noção de trauma em Psicanálise. 2009. Tese. (Tese de Doutorado em Psicología Clínica) - Psicanálise Clínica e cultura - PUC-Rio, Rio de Janeiro, 2009.

FREUD, S. (1886) Relatório Sobre Meus Estudos Em Paris E Berlim. In. Obras Completas, Volume 1: Publicações Pré-Psicanalíticas E Esboços Inéditos (18861889) (p.39-52). Rio De Janeiro: Imago, 1996.

(1886) Teoria Dos Ataques Histéricos. In.Obras Completas, Volume 1: Publicações Pré-Psicanalíticas E Esboços Inéditos (1886-1889) (p.39-52). Rio De Janeiro: Imago, 1996.

(1892) Sobre a Teoria Dos Ataques Histéricos. In.Obras Completas, Volume 1: Publicações Pré-Psicanalíticas E Esboços Inéditos (1886-1889) (p.3952). Rio De Janeiro: Imago, 1996., 1996.

(1895).Projeto para uma psicologia científica. In. Obras Completas, Volume 1: Publicações Pré-Psicanalíticas E Esboços Inéditos (1886-1889) (p.3952). Rio De Janeiro: Imago, 1996.

(1910) A concepção psicanalítica da perturbação psicogênica da visão.In.Obras completas Vol 11: Cinco lições da psicanálise Leonardo Da Vinci e outros Trabalhos (1910).Rio de Janeiro: Imago (1996)

(1893-1895). Sobre O Mecanismo Psíquico Dos Fenômenos Histéricos. In. Obras Completas, Volume 2:Estudos Sobre A Histeria. (18931895) (p.18-38). São Paulo: Companhia Das Letras, 2016.

(1900) A interpretação dos sonhos. In.Obras Completas, Volume 4: Interpretação dos sonhos (1900). São Paulo: Companhia das Letras, 2019

(1905). Três ensaios da sexualidade.In. Três Ensaios sobre a sexualidade, Análise Fragmentaária De Uma Histeria ("OCaso Dora") e Outros Textos (1901-1905). São Paulo: Companhia das letras, 2016

(1912-1913). Totem e Tabu. In.Obras completas Vol. 11: Totem e Tabu, Contribuição À História Do Movimento Psicanalítico e outros textos(19121914). São Paulo: Companhia Das Letras, 2012

(1914). Introdução ao narcisismo. In. Obras Completas Vol.12:

Introdução ao Narcisismo, Ensaios de Metapsicologia e Outros Textos (19141916). São Paulo: Companhia Das Letras, 2010 
(1915). Considerações Atuais Sobre A Guerra E Morte. In.Obras Completas, Volume 12: Introdução Ao Narcisimo, Ensaio De Metapsicologia E Outros Textos (1914-1916). São Paulo: Companhia Das Letras, 2010.

(1917). Fixação no trauma, O Inconsciente. In. Obras Completas, Volume 13: Conferências Introdutórias À Psicanálise (1916-1917) (p.364-380). São Paulo: Companhia Das Letras, 2014.

(1917).Luto e melancolia. In.Obras Completas Vol.12: Introdução ao Narcisismo, Ensaios de Metapsicologia e Outros Textos (1914-1916). São Paulo: Companhia Das Letras,2010.

(1919). Introdução A Psicanálise Das Neuroses De Guerra. In. Obras Completas, Volume 14: História De Uma Neurose Infantil ("O Homem Dos Lobos”), Além Do Princípio Do Prazer E Outros Textos. (1917-1920) (p.982388). São Paulo: Companhia das Letras, 2010

(1920). Além Do Princípio Do Prazer. In. Obras Completas, Volume 14: História De Uma Neurose Infantil ("O Homem Dos Lobos"), Além Do Princípio Do Prazer E Outros Textos. (1917-1920) (p.161-239) São Paulo: Companhia Das Letras, 2010.

(1921).Psicologia das Massas e Análise do Eu. In. Obras Completas, Vol. 15: Psicologia das Massas E Análise Do Eu E Outros Textos (1920-1923) (p.13-113). São Paulo: Companhia das Letras, 2011

(1923). O Eu e o Id.In. Obras Completas Vol.16: O Eu e o Id, "Autobiografia" e outros textos (1923-1925). São Paulo: Companhia das Letras.2011

(1917). O Futuro de uma Ilusão. In. Obras Completas, Vol. 17: Inibição, Sintoma E Angústia, O Futuro de Uma Ilusão E outros Textos (19261929) (p.231-301). São Paulo: 2014.

(1930). O Mal-Estar Na Civilização. In. Obras Completas Vol. 18: O Mal-Estar Na Civilização, Novas Conferências Introdutórias À Psicanálise E outros Textos (1930-1936) (p.13-123). São Paulo: Companhia Das Letras, 2010

(1932). Por Que A Guerra? In. Obras Completas Vol. 18: O MalEstar Na Civilização, Novas Conferências Introdutórias À Psicanálise E outros Textos (1930-1936) (p.417-435). São Paulo: Companhia Das Letras, 2010

(1939).Moisés e o Monoteísmo. In. Obras Completas Vol. 19: Moisés e o Monoteísmo, Compêndio de Psicanálise e Outros Textos (1937-1939) (p.13188) São Paulo: Companhia Das Letras, 2018.

GELLNER, E. Nations and nationalism. Ithaca, NY: Cornell University Press, 1983.

GINZBURG, J. Literatura, Trauma e Melancolia. Campinas: Autores Associados, 2012

GRAZYZEL, S. Women'sIdentitiesat War: Gender, Motherhood and Politics in Britain and France during First World War. Chapel Hill: University of Carolina Press, 1999.

GREEN, A. Pulsão de morte, narcisismo negativo função desobjetalizante . Em R. I. York, Pulsão de Morte. São Paulo: Escuta, 1988. 
GREEN, A. La folie privée. Paris: Gallimard, 1990.

GREEN, A. Le Travail du Négatif. Paris: Minuit, 1993

GREEN . La mort dans la vie. La pensée clinique. Paris: Odile Jacob, 2002.

GREEN, A. Les cas limite. De la folie privée aux pulsions de destructions et de mort. Revue Française de Psychanalyse, 2 (75), 2011.

HAMANN, P. F. (2010). Violência Guerra e Política Segundo o Pensamento Freudiano. 2010. Dissertação (Dissertação De Mestrado, Programa De PósGraduação Em Teoria Psicanalítica) - Instituto De Psicologia - Universidade Federal Do Rio De Janeiro, 2010.

HAYES, C. Nationalism: A religion. New York: Macmillan, 1960.

HOOKS, B. E eu não sou uma mulher?: mulheres negras e o feminismo Rio de Janeiro: Rosa dos tempos, 2020.

IGNATIEFF, M. Blood and belonging: journeys into new nationalism. London: Viking, 1993.

JANIN, C. Au coeur de la theorie psychanalytique: le traumatisme. Le traumatisme psychique: organisation et desorganization. Paris : PUF, 2005.

JUNIOR, J. N ; BESSET, V. L. Violência e sintoma: o que a psicanálise tem a dizer? Fractal: Revista De Psicologia, 323-336, 2010.

KAMUZINZI, M. Understanding the innermost nature of genocidal rape: A community-based approach. RwandaJournal, (1) 62-87, 2017. Disponível em: https://www.ajol.info/index.php/rj/article/view/163304 Acesso em: fevereiro de 2020

KAPCZINSKI, F; MARGIS, R. Transtorno de Estresse Pós-Traumático: Critérios Diagnósticos. Revista Brasileira de Psiquiatria, 2003. Disponível em: http://www.scielo.br/pdf/\%0D/rbp/v25s1/a02v25s1.pdf Acesso em: fevereiro de 2020

KLAUTAU, P., KISLANOV, S. \& WINOGRAD, M. A função terapêutica do traumático. Caderno Psicanalítico, 151-168, 2014.

KNOBLOCH, F. O Tempo Do Traumático, São Paulo, Educ, 1998.

KORAC, M. (1998). Ethnic-Nationalism, Wars And The Patterns Of Social, Political And Sexual Violence Against Women: The case of post-Yugoslav countries. Identities, 153-181,1998 .

LAPLANCHE, J.; PONTALIS, J.-B. (1982) Vocabulário da Psicanálise. São Paulo: Martins Fontes, 2016.

LEJARRAGA, A, L. O Trauma E Seus Destinos. Rio De Janeiro, Revinter, 1996.

LEVENKRON, Nomi. Death and the Maidens: "prostitution", Rape, and sexual Slavery During World War II. Hebrew University of Jerusalem, 2010

LIMA, G. Q ; WERLANG, B. S. Mulheres Que Sofrem Violência Doméstica: Contribuição Da Psicanálise. Psicologia Em Estudo, 511-520, 2011.

MAIA, M. S. Extremos da alma: dor e trauma na atualidade e clínica psicanalítica. Rio de Janeiro: Garamond, 2005. 
MALDONADO, G. Neurose Traumática. Curitiba: Jaruá, 2012.

MALDONADO, G; CARDOSO, M. (2009). O Trauma Psíquico Das Narrativas Impossíveis, Mas Necessárias. Psicologia Clínica. Disponível em :

http://www.scielo.br/pdf/pc/v21n1/v21n1a04.pdf Acesso em: fevereiro de 2021

MARTINS, N. S. (In)Segurança Das Mulheres No Conflito Da Ex-Iuguslávia: Uma Análise Pela Perspectiva da Psicologia Política e da Segurança Humanna Feminista. Revista Latino-Americana de Estudos em Cultura e Sociedade, 318-339, 2016. Disponível em:

http://periodicos.claec.org/index.php/relacult/article/view/329 Acesso em: março de 2020.

MARTINS, N. S. O Estupro Como Arma De Guerra: Violência Sexual E

Reprodutiva. In: Seminário Internacional de educação e sexualidade. Vitória, Espírito Santo, 2016. Recuperado de:

http://www.gepsexualidades.com.br/resources/anais/6/1467425708_ARQUIVO_

Oestuprocomoarmadeguerraviolenciasexualereprodutiva.pdf Acessado em: junho de 2020

MONTEIRO, D. D. Guerra. Freud explica? Cógito, 2002.

MOORE, J. Confronting Rape As A War Crime. Global Researcher, v. 4, n. 5, 105-130, 2010 Disponível em:

http://library.cqpress.com/cqresearcher/document.php?id=cqrglobal2010050003

Acesso em: março de 2020

MULLINS, C. W. He Would Kill Me With His Penis: Genocidal Rape in Rwanda as a State Crime. Critical Criminology: An International Journal, 15-33, 2009.

NIARCHOS, C. N. Women, War, And Rape. Human Rights Quarterly: A

Comparative And International Journal Of The Social Sciences, Humanities, And Law, pp. 649-690, 1995.

OLIVEIRA, F. H.; HERZOG, R. (2010). Guerra, Violência E Pulsão De Morte: Uma Articulação Não Evidente. Psicologia em Estudo, 2010.

OLIVEIRA, M. (2014). Trauma, Repetição e Pulsão De Morte: negatividade necessária. 2014. Dissertação. (Dissertação em psicologia clínica) - Psicanálise, Clínica e Cultura. - PUC-Rio, Rio de Janeiro, 2014.

OLIVEIRA, M. T.; WINOGRAD, M., ; FORTES, I. A Pulsão de Morte Contra a Pulsão de Morte: a Negatividade Necessária. Psicologia Clinica, 28(2), 88, 2016. Disponível em http://pepsic.bvsalud.org/pdf/pc/v28n2/05.pdf Acesso em: junho 2021.

OLIVEIRA, B.; JUNIOR, J. O estupro como estratégia de guerra em conflitos armados: a experiência do tribunal penal internacional para a antiga Iugoslávia nos casos de violência de gênero. Brazilian Journal of International Relations, 97-116, 2019.

ORGANIZAÇÃO MUNDIAL DE SAÚDE. Violência Contra Mulher, 2017.

ORGANIZAÇÃO PAN-AMERICANA DE SAÚDE. 2017. Disponível em: https://www.paho.org/bra/index.php?option=com_content\&view=article\&id=566 9:folha-informativa-violencia-contra-as-mulheres \&Itemid=820 Acesso em: fevereiro de 2020 
PASSOS, K. R., \& LOSURDO, F. Estupro De Guerra: O Sentido Da Violação Dos Corpos Para O Direito Penal Internacional. Revista de Gênero, Sexualidade e Direito. v. 3, 153 - 169, 2017.

PEREIRA, H. H., \& CAVALCANTI, S. C. A Prática Do Estupro De Mulheres Como Estratégia De Guerra Sob O Viés Do Direito Internacional. Revista Tema, 16, 2015.

PEREIRA, S. W. As pulsões de morte e seus derivados: Os avatares da teoria. 2006. Tese (Tese de Doutorado Programa de Pós-Graduação em Teoria Psicanalítica) - Instituto de Psicologia - Universidade Federal do Rio de Janeiro, Rio de Janeiro, 2006.

PERES, A. C. Campos de Estupro: As Mulheres E A Guerra Na Bósnia. cadernos pagu, 117-162, 2011.

PERES, A. C. O Debate Sobre A Representação Da Diferença E O Significado Da Guerra Na Bósnia-Herzegóvina. Horizontes Antropológicos, 2013

ROPTIN, J. Des Viols De Guerre À La Violence Sexuelle Comme Terreur. Mémoires , 5-7, 2019.

ROUDINESCO, E. Na sua época e em nosso tempo. Rio de Janeiro: Zahar, 2016.

RUDGE, A. M. Trauma. Rio de Janeiro: Zahar, 2009.

RUDGE, A. M. Sonhos traumáticos na clínica psicanalítica. Revista

Latinoamericana De Psicopatologia Fundamental, 603-615, 2016.

SAFFIOTI, H. B. Gênero, Patriarcado E Violência. São Paulo: Fundação Perseu Abramo, 2004.

SALZMAN, T. A. Rape Camps as a Means of Ethnic Cleansing: Religious, Cultural, and Ethical Responses to Rape Victims in the Former Yugoslavia. Human Ríghts Quarterly, 348-378, 1998.

SCHESTATSKY, S. et al. A Evolução Histórica Do Conceito De Estresse PósTraumático. Revista Brasileira de Psiquiatria, 2003.

SEIFERT, R. The Female Body as Political Body: Rape, War and the Nation. Direttore responsabile, 2, 241-254, 2007.

SKJELSBÆK, I. Sexual Violence In Times Of War: A New Challenge For Peace Operations? International Peacekeeping, 69-84, 2001.

SOARES, C. A Proteção Internacional Dos Refugiados e o Sistema Brasileiro De Concessão De Refúgio. Âmbito Jurídico, 2011.

SOARES, C. (2012). O Direito Internacional Dos Refugiados E O Ordenamento Jurídico Brasileiro: Análise Da Efetividade Da Proteção Nacional . 2012. Dissertação (Dissertação em Direito) - Curso de direiro Uiversidade Federal de Alagoas , Maceió, 2012

SOUZA, M. L. Violência . São Paulo: Casa do Psicólogo, 2005.

SUPERINTÊNDENCIA DE DIREITOS DA MULHER/ SECRETARIA DE ESTADO DE ASSISTÊNCIA SOCIAL E DIREITOS HUMANOS. Uma Vida Sem Violência É Um Direito Das Mulheres: "Em Briga De Marido E Mulher O Poder Público mete a colher". Rio de Janeiro, 2013. 
TIBURI, M. Feminismo Em Comum: Para Todas, Todes E Todos.Rio de Janeiro: Rosa dos Tempos, 2020.

TODOROVA, T. Giving Memory a Future': Confronting the Legacy of Mass Rape in Post-conflict Bosnia-Herzegovina. Journal of International Women's Studies, 3-15, 2011.

TREIS, M. E. ; MORAIS, P. S. Estupro Genocida: Como A Tática De Guerra Marcou A Sociedade Ruandesa. Revista Perspectiva, 11,21, 2018.

TURRA, K. K.; OBREGÓN, M. F. Uma breve análise dos tribunais penais internacionais ad hoc: violação ao princípio do juiz natural? Revista de direito internacional e globalização econômica, 2019

UCHITEL, M. Neurose Traumática. São Paulo: Casa do Psicólogo, 2011.

UNITED NATIONS. Conflict-related sexual violence: Report of the Secretary-General, 2014.Disponível em:

https://www.un.org/en/ga/search/view_doc.asp?symbol=S/2014/181Acesso em: fevreiro de 2020

- Guidance note of the secretary-general. (2014) Reparations for

Conflict-Related Sexual Violence, 2014. Disponível

em: https://www.ohchr.org/Documents/Press/GuidanceNoteReparationsJune2014.pdf.Acesso em: junho 2020

Security Council, Report of the Commission of Experts Established Pursuantto United Nations Security Council Resolution 780 (1992), 27 May 1994, s/1994/674, Disponível em: https://www.refworld.org/docid/582060704.html Acesso em: junho 2020

VAN DER Hart; FRIEDMAN, B. A Reader's Guide To Pierre Janet: A Neglected Intellectual Heritage. Dissociation 2(1):3-16, 1989.

VILHENA, J; ZAMORA, M. Além Do Ato: Os Transbordamentos Do Estupro. Dossiê Temático. Revista Rio de Janeiro, 2004.

VITTO, D. D.; GILL, A.; SHORT, D. A Tipificação Do Estupro Como Genocídio. Revista internacional de direitos Humanos, 28-51, 2009.

VIZENTINI, P. A fragmentação da Iugoslávia: paradigma da afirmação das estruturas hegemônicas de poder. Indicadores Econômicos124-136, 1999

WINOGRAD, M. O Homem Sem Resto. In: II Seminário de Morte, Arte Fúnebre e Patrimônio. Rio de Janeiro, 2019.

WINOGRAD, M, KLAUTAU, P.; SOLLERO DE CAMPOS, F. Entre o trauma e o traumático: a lesão cerebral de Pedro e o presente permanente. Winograd, M. E Vilhena, J. (Orgs) Psicanálise e clínica ampliada: multiversos. Curitiba, Appris, 2014. 